\title{
Exploratory Study of Complexant Concentrate Waste Processing
}
G. J. Lumetta
L. A. Bray
D. E. Kurath
J. R. Morrey
J. L. Swanson
D. W. Wester

February 1993

Prepared for the U.S. Department of Energy under Contract DE-AC06-76RLO 1830

Pacific Northwest Laboratory Operated for the U.S. Department of Energy by Battelle Memorial Institute 


\title{
DISCLAIMER
}

This report was prepared as an account of work sponsored by an agency of the United States Government. Neither the United States Government nor any agency thereof, nor Battelle Memorial Institute, nor any of their employees, makes any warranty, expressed or implied, or assumes any legal liability or responsibility for the accuracy, completeness, or usefulness of any information, apparatus, product, or process disclosed, or represents that its use would not infringe privately owned rights. Reference herein to any specific commercial product, process, or service by trade name, trademark, manufacturer, or otherwise does not necessarily constitute or imply its endorsement, recommendation, or favoring by the United States Government or any agency thereof, or Battelle Memorial Institute. The views and opinioris of authors expressed herein do not necessarily state or reflect those of the United States Government or any agency thereof.

\author{
PACIFIC NORTHWEST LABORATORY \\ operated by \\ BATTELLE MEMORIAL INSTITUTE \\ for the \\ UNITED STATES DEPARTMENT OF ENERGY \\ under Contract DE-ACO6-76RLO 1830
}

\author{
Printed in the United States of America
}

Available to DOE and DOE contractors from the

Office of Scientific and Technical Information, P.O. Box 62, Oak Ridge, IN 37831 . prices available from (615) 576-8401. FTS 626-8401.

Available to the public from the National Technical Information Service, U.S. Department of Commerce, 5285 Port Royal Rd., Springfield, VA 22161 


\section{EXPLORATORY STUDY OF COMPLEXANT} CONCENTRATE WASTE PROCESSING
G. J. Lumetta
L. A. Bray
D. E. Kurath
J. R. Morrey
J. L. Swanson
D. W. Wester

February 1993

Prepared for

the U.S. Department of Energy

under Contract DE-AC06-76RLO 1830

Pacific Northwest Laboratory

Richland, Washington 99352

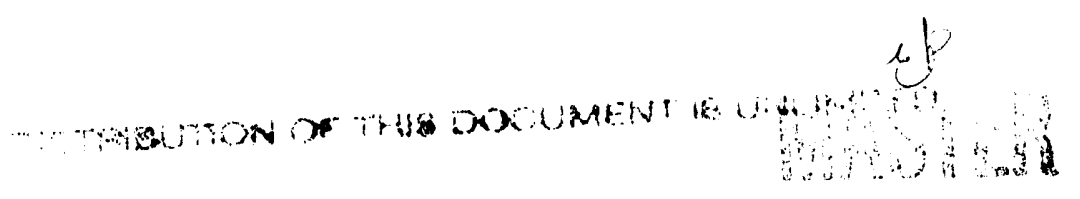




\section{SUMMARY}

The purpose of this exploratory study, conducted by Pacific Northwest Laboratory for Westinghouse Hanford Company, was to determine the effect of applying advanced chemical separations technologies to the processing and disposal of high-level wastes (HLW) stored in underground tanks. The major goals of this study were to determine 1) if the wastes can be partitioned into a small volume of HLW plus a large volume of low-level waste (LLW), and 2) if the activity in the LLW can be lowered enough to meet NRC Class A LLW criteria.

This report presents the results obtained in a brief scouting study of various processes for separating radionuclides from Hanford complexant concentrate (CC) waste. This type of waste was chosen for study because of its complexity and the demands that it would impose on chemical separations technology. Also, CC waste is the most voluminous of the Hanford double-shell tank wastes currently considered to require pretreatment. Implementation of advanced separation processes would allow the bulk of the waste to be disposed of as Class $A$ LLW, an option much less costly than geologic disposal of $H L W$.

This report presents the following conclusions:

- Complete dissolution of CC waste solids (in nitric acid-based solutions) will probably be achievable.

- Methods to separate $C S$ and Pu from alkaline CC waste supernate are available (these involve sorption processes).

- The separation of Tc from either alkaline or acidic solution can be achieved by extraction with tetraalkylammonium compounds.

- Technologies for the removal of $\mathrm{Sr}$ and Am from alkaline CC waste supernate require development.

- Technologies for the removal of CS from acidic solution require development.

- All advanced separation methods, even those identified as promising, require further research to develop practical processes that will meet Class A LLW criteria and result in a minimum quantity of HLW. 
- To minimize waste volumes, the best approach to the pretreatment of CC waste involves separation of the sludge and supernate, dissolution of the sludge, and separate processing of the dissolved sludge solution and the alkaline supernate. However, unless suitable methods are developed to separate ${ }^{241} \mathrm{Am}$ and ${ }^{90} \mathrm{Sr}$ from alkaline $\mathrm{CC}$ supernate, direct acidification of the entire CC waste followed by TRUEX and SREX processing will be necessary to separate these radionuclides. 


\section{ACKNOWLEDGMENTS}

This study was funded by Westinghouse Hanford Company (WHC) through the Alternative Analysis Department, J. J. Holmes, Manager. We wou?d like to thank R. G. Cowan for numerous valuable discussions and M. J. Wagner for much of the experimental work.

We appreciate the assistance of the following personnel from the Analytical Chemistry Department: C. 0. Harvey, M. W. Urie, D. E. Rinehart, S. W. Thompson, S. I. Barsoum, P. K. Melethil, and J. H. Ennen. We are grateful for the contributions of D. M. Camaioni, B. Harris, and J. C. Linehan in the synthesis of 4-(1-methy1-1-octylnonyl)catechol. 


\section{ACRONYMS}

$\begin{array}{ll}\text { ANL } & \text { Argonne National Laboratory } \\ \text { CC } & \text { complexant concentrate } \\ \text { CMPO } & \text { carbamoylmethylphosphine oxide } \\ \text { DF } & \text { decontamination factor } \\ \text { DST } & \text { double-shell tank } \\ \text { EDTA } & \text { ethylenediaminetetraacetate } \\ \text { HDDNS } & \text { didodecylnaphthalenesulfonic acid } \\ \text { HDNNS } & \text { dinonylnaphthalenesulfonic acid } \\ \text { HEDTA } & \text { hydroxyethylenediaminetriacetate } \\ \text { HLW } & \text { high-level waste } \\ \text { LLW } & \text { low-level waste } \\ \text { MONC } & \text { 4-(1-methyl-1-octylnonyl) catechol } \\ \text { NCA } & \text { neocarboxylic acid } \\ \text { NPH } & \text { normal paraffin hydrocarbon } \\ \text { NRC } & \text { U.S. Nuclear Regulatory Commission } \\ \text { NTA } & \text { nitrilotriacetate } \\ \text { PNL } & \text { Pacific Northwest Laboratory } \\ \text { SREX } & \text { strontium extraction process } \\ \text { TBAH } & \text { tetra-n-butylammonium hydroxide } \\ \text { TBAN } & \text { tetra-n-butylammonium nitrate } \\ \text { TBP } & \text { tributylphosphate } \\ \text { TC } & \text { total carbon } \\ \text { TCMA } & \text { tricaprylmonomethyl ammonium nitrate } \\ \text { TOAB } & \text { tetra-n-octylammonium bromide } \\ \text { TOC } & \text { total organic carbon } \\ \text { TRU } & \text { transuranic waste } \\ \text { TRUEX } & \text { WHC }\end{array}$




\section{CONTENTS}

SUMMARY .................................

ACKNOWLEDGMENTS ....................

ACRONYMS ................................... vii

1.0 INTRODUCTION . . . . . . . . . . . . . . . . . . . 1.1

2.0 METHODS AND MATERIALS . . . . . . . . . . . . 2.1

2.1 CC SOLIDS DISSOLUTION . . . . . . . . . . . . . 2.2

2.2 PREPARATION OF SYNTHETIC CC WASTE . . . . . . . 2.2

2.3 ACIDIFICATION OF CC WASTE . . . . . . . . . . . 2.4

2.4 SOLVENT EXTRACTION EXPERIMENTS . . . . . . . . . . . . 2.4

2.5 BATCH DISTRIBUTION EXPERIMENTS . . . . . . . . . 2.6.

2.6 EVALUATION OF SILICA-SUPPORTED MACROCYCLE FOR REMOVAL OF CS . . . . . . . . . . . . . . 2.6

2.7 MACRORETICULAR SUPPORT IMPREGNATED WITH SODIUM NICKEL

FERROCYANIDE (FECN-XAD-4) FOR THE REMOVAL OF CS . . . . 2.7

2.8 PRECIPITATION OF CS WITH SODIUM PHOSPHOTUNGSTATE $\ldots \ldots$.

3.0 RESULTS AND DISCUSSION . . . . . . . . . . . . . . . . 3.1

3.1 ChaRACTERIzATION OF CC WASTE SAMPLES ............ 3.1

3.2 CC SOLIDS DISSOLUTION . . . . . . . . . . . . . 3.3

3.3 SEPARATIONS FROM ACIDIC SOLUTION . . . . . . . . . 3.7

3.3.1 Separation of CS from Acidic Solution . . . . 3.7

3.3.2 Separation of $T C$ from Acidic Solution ..... 3.12

3.3.3 Separation of Sr from Acidic Solution ..... . 3.14

3.4 SEPARATIONS FROM ALKALINE SOLUTION .......... 3.15

3.4.1 Sorption Processe's . . . . . . . . . . . 3.15

3.4.2 Solvent Extraction Methods . . . . . . . . . 3.16 
3.5 TESTS WITH ACTUAL CC WASTE . . . . . . . . . . . . 3.20

3.5.1 Precipitation of Cs with Sodium Phosphotungstate . . 3.21

3.5.2 TRUEX: Behavior of TRUs and TC . . . . . . . . 3.22

3.5.3 SREX: Behavior of $\mathrm{Sr}$ and $\mathrm{TC} . . . . . . . . . .3 .23$

3.5.4 Solid Sorbents ................ . . 3.24

4.0 CONCEPTUAL FLOWSHEETS ............................ 4.1

5.0 DIRECTIONS FOR FUTURE RESEARCH . . . . . . . . . . . . . 5.1

5.1 CC SOLIDS DISSOLUTION ............... 5.1

5.2 SEPARATION OF CS FROM ACIDIC SOLUTION . . . . . . . . . . 5.1

5.3 SEPARATION OF TC ................. 5.2

5.4 SORPTION OF TRUS, Sr, CS, AND TC . . . . . . . . . 5.2

5.5 REMOVAL OF ${ }^{96} \mathrm{Sr}$.AND Am FROM ALKALINE CC WASTE SUPERNATE . . 5.3

6.0 REFERENCES ................................. 6.1 


\section{FIGURES}

1.1 Options for the Pretreatment of CC Waste . . . . . . . . . 1.3

3.1 Breakthrough Curve for Sorption of $\mathrm{Cs}$ on $\mathrm{Si}-\mathrm{L}$. . . . . . . . 3.8

3.2 Breakthrough Curve for the Sorption of $\mathrm{CS}$ on $\mathrm{FeCN}-\mathrm{XAD}-4$. . . 3.9

3.3 Extraction of Cs with $0.05 \mathrm{M}$ DtBB21C7 and $0.05 \mathrm{M}$ HDNNS in Toluene ................ 3.10

3.4 Extraction of TC with $0.1 \mathrm{M}$ TOAB in Cyclohexanone and 0.2 M TCMA in 1-0ctanol as a Function of $\mathrm{HNO}_{3}$ Concentration .................. 3.12

4.1 Conceptual Processing Flowsheet--CC Waste . . . . . . . . . . 4.1

4.2 Alternative Processing Sequence Alkaline CC Waste . . . . . . . 4.3 


\section{TABLES}

1.1 NRC Class A LLW Criteria .................. 1.1

2.1 Composition of the Synthetic CC Waste Supernate . . . . . 2.3

2.2 Composition of Acidified Actual and Synthetic CC Waste . . . 2.5

3.1 Composition of Actual and Synthetic CC Waste Supernates ... . 3.2

3.2 Radionuclide Content of CC Waste Supernate . . . . . . 3.3

3.3 Components of Actual CC Solids That Dissolved by $\ldots \ldots \ldots$. . . . 3.4
Dilution With Water . . . . . . . . . . . .

3.4 Summary of Actual CC Solids Dissolutio. . . . . . . . . 3.5

3.5 Quantities of Actual CC Waste Components . . . . . . 3.6

3.6 Extraction of Cs with DtBB21C7 and HDNNS . . . . . . 3.11

3.7 Extraction of Tc from Acidic Solution .......... 3.13

3.8 Batch Distribution Ratios for $\mathrm{Sr}, \mathrm{Cs}, \mathrm{Am}, \mathrm{Pu}$, and TC . . . 3.16

3.9 Extraction of Sr with $0.05 \underline{M} \mathrm{DC} 18 \mathrm{CC} 6+0.1 \underline{\mathrm{M}} \mathrm{NCA}$ in Toluene . 3.17

3.10 Extraction of TC from Alkaline Solution . . . . . . . 3.18

3.11 Reductive Stripping of $T C \ldots . . . . . . . . .3 .19$

3.12 Extraction of $\mathrm{Tc}$ from $5 \mathrm{M} \mathrm{NaNO}_{3}$ Solution with $0.1 \mathrm{TOAB}$ in 3.19

3.13 Extraction of Am from Alkal ine Solution with
Alkylated Catechols . . . . . . . . . . 3.20

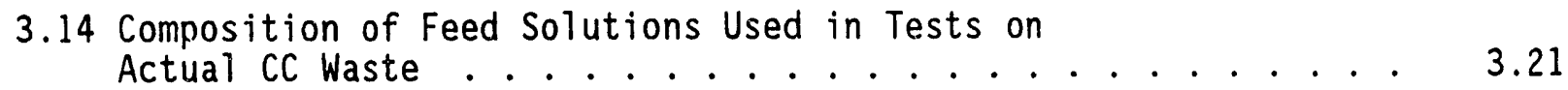

3.15 TRUEX Experiment with Actual CC Waste . . . . . . . 3.22

3.16 SREX Experiment with Actual CC Waste . . . . . . . . . 3.24

3.17 Batch Distribution Ratios for Sr, Cs, Am, Pu, and TC, . . . . . 3.24
Obtained with Actual CC Waste . . . . . .

5.1 Disadvantages of Acid-Side Cs Separations ........ 5.2 


\subsection{INTRODUCTION}

For over 40 years, one of the primary missions of the Hanford Site was to produce ${ }^{239} \mathrm{Pu}$. During the course of this effort, various high-level wastes (HLW) and transuranic wastes (TRU) were generated and stored in underground carbon-steel tanks. Today cleanup and closure of these tanks is a major mission of the Hanford Site. The current baseline for this activity includes retrieval of wastes from the tanks and, for selected waste types, partitioning into a relatively large volume of low-level waste (LLW) and a small volume of HLW. The LLW will be cast in grout and disposed of onsite in near-surface vaults, while the HLW will be vitrified and disposed of in a geologic repository. Because of the high costs of vitrification and geologic disposal (compared to disposal as grout), it is desirable to minimize the amount of HLW; chemical separations will pla: : key role in this minimization.

The purpose of this exploratory study, conducted by Pacific Northwest Laboratory $(P N L)^{(a)}$ for Westinghouse Hanford Company (WHC), is to determine the effects of applying advanced chemical separations technologies to the processing and disposal of HLW. While no criteria have yet been established for the LLW portion of the treated waste, for this study it was assumed that U.S. Nuclear Regulatory Commission (NRC) Class A LLW criteria would have to be met (Table 1.1).

TABLE 1.1. NRC Class A LLW Criteria

\begin{tabular}{|c|c|}
\hline Nuclide & $\begin{array}{c}\text { Maximum } \\
\text { Concentration }\end{array}$ \\
\hline${ }^{137} \mathrm{Cs}$ & $1 \mathrm{Ci} / \mathrm{m}^{3}$ \\
\hline${ }^{90} \mathrm{Sr}$ & $0.04 \mathrm{Ci} / \mathrm{m}^{3}$ \\
\hline${ }^{99} \mathrm{Tc}$ & $0.3 \mathrm{Ci} / \mathrm{m}^{3}$ \\
\hline TRU & $10 \mathrm{nCi} / \mathrm{g}$ \\
\hline
\end{tabular}

(a) Pacific Northwest Laboratory is operated by Battelle Memorial Institute for the U.S. Department of Energy under Contract DE-AC06-76RLO 1830. 
Of the tank wastes stored in double-shell tanks (DST) at Hanford, the waste type known as "complexant concentrate" (CC) presents the greatest challenge in terms of separation chemistry. This waste contains complexants such as ethylenediaminetetraacetate (EDTA), hydroxyethylenediaminetriacetate (HEDTA), nitrilotriacetate (NTA), and citrate; also present are degradation products of these complexants. Because of the complexants, certain ions including $\mathrm{Fe}^{3+}, \mathrm{Sr}^{2+}$, and TRUs are in solution that would have otherwise precipitated under the alkaline conditions present in this waste. The effects of these complexants on separation processes are not fully known. Because most radionuclide separation processes are driven by complexation phenomena, it is expected that the presence of complexants hinders rather than enhances separations. For this reason, $C C$ waste was chosen as the subject of this exploratory processing study. Many of the chemical separation processes that are successfully used for $C C$ waste will likely be applicable to other Hanford tank wastes.

Figure 1.1 summarizes possible scenarios for the pretreatment of CC waste. Three routes are considered. The first step in option I is the destruction of the complexants under alkaline conditions, which would result in the precipitation of the TRUs and ${ }^{90} \mathrm{Sr}$. After removal of ${ }^{99} \mathrm{TC}$ and ${ }^{137} \mathrm{Cs}$, the supernatant solution might qualify as Class $A$ LLW. The precipitated solids and the solids originally present are dissolved and the various radionuclides (TRUs, ${ }^{90} \mathrm{Sr},{ }^{137} \mathrm{Cs}$, and ${ }^{99} \mathrm{TC}$ ) are separated. Toxic metals such as chromium might also be removed from the LLW stream before nitrate separation/ destruction. Option II involves the separation of the CC supernate from the solids. The alkaline supernate is treated to remove TRUs, ${ }^{90} \mathrm{Sr},{ }^{137} \mathrm{Cs}$, and ${ }^{99} \mathrm{Tc}$. The complexants are then destroyed and nitrate ion removed or destroyed. The solids are dissolved and treated much the same as those in Option I. Option III involves direct acidification of the CC supernate/solids mixture to dissolve the solids. TRUs, ${ }^{90} \mathrm{Sr},{ }^{137} \mathrm{Cs},{ }^{99} \mathrm{Tc}$, and possibly toxic metals are removed, then the complexants are destroyed and nitrate is removed or destroyed.

Possible technologies for each required separation appear in Figure 1.1. This information is not exhaustive, but serves as a guideline to identify 


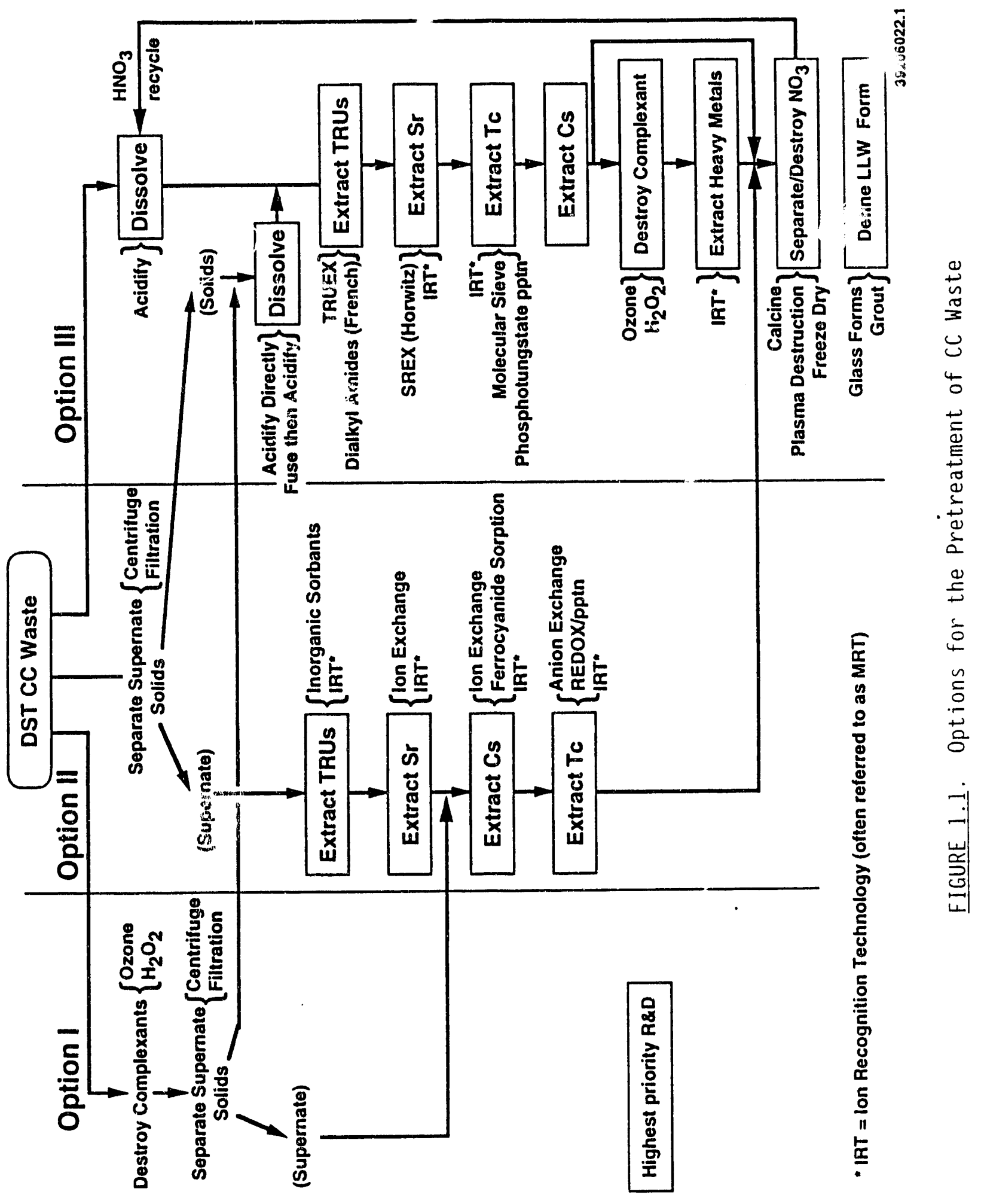

1.3 
those areas where established separation methods are not available. These areas are identified by bold boxes in Figure 1.1. This work has focused on five senaration problems: separation of 1) Cs from acid solution, 2) Tc from acid solution, 3) TRUs from alkaline solution, 4) Sr from alkaline solution, and 5) $1 ;$ from aikaline solution. In addition to these separation problems, the problem of dissolution of CC waste solids was also addressed in this study. 


\subsection{METHODS AND MATERIALS}

The following is a brief description of materials and sources: dicyclohexano-18-crown-6 (DC18C6), 4-t-butylcatechol, 3,5-di-t-buty1catechol, and 1-octanol were obtained from R.1drich Chemical Co. (Milwaukee, Wisconsin). Dinonylnaphthalenesulfonic acid (HDNNS), tetra-n-butylammonium hydroxide (TBAH) (55\% aqueous solution), and tetra-n-octylammonium bromide (TOAB) were purchased from Alfa Products (Ward Hill, Massachusetts). The TBAH was converted to tetra-n-butylasmonium nitrate (TBAN) by neutralization with $\mathrm{NHO}_{3}$. Di-t-butylbenzo-21-crown-7 was donated by Prof. Richard Bartsch of Texas Tech University. Neocarboxylic acid (NCA) was obtained from ETRAC, Inc. (Knoxville, Tennessee). A proprietary experimental Cs-selective chromatographic material consisting of a macrocycle bound to silica gel was provided by IBC Technologies, Inc. (Provo, Utah). This material will hereafter be referred to as "Si-L." The TRUEX(a) process solvent [0.2 M octyl (phenyl)$\mathrm{N}, \mathrm{N}$-diisobutylcarbamoylmethylphosphine oxide (CMPO) $+1.4 \mathrm{M}$ tributylphosphate (TBP) in normal paraffin hydrocarbon (NPH)] was obtained from WHC. The TRUEX solvent was washed successively with sodium carbonate solution and water before use. Resorcinol-formaldehyde organic ion exchange resin (BSC-187) was obtained from Boulder Scientific Co. (Eoulder, Colorado). Phenol-formaldehyde cation-exchange resin ( $\mathrm{Na}-\mathrm{form})(A R C-359)$ and the granular phenol-formaldehyde condensation polymer ( $\mathrm{H}$-form) (CS-100) were purchased from Diamond Shamrock Co. (Cleveland, Ohio). Sodium aluminosilicate zeolite (chabazite structure) with (TIE-96) and without (IE-96) $5 \mathrm{wt} \% \mathrm{TiO}_{2}$ were supplied by UOP (Tarrytown, New York). Tricaprylmonomethylammonium chloride was obtained from General Mills Chemical Division.

4-(1-Methy 1-1-octylnony 1) catechol (MONC) was syntheiszed from n-octanol, methyl acetate, and catechol. The three step synthesis involved: 1) conversion of $n$-octanol to $n$-bromooctane by reaction with sulfuric acid and sodium bromide; 2) reaction of $n$-bromooctane with $\mathrm{Mg}$ to give the $\mathrm{Mg}\left[\left(\mathrm{CH}_{2}\right)_{7} \mathrm{CH}_{3}\right]_{2}$, which was then reacted with methyl acetate to give 9-methyl-9-heptadecanol; and 3) alkylation of catechol with 9-methyl-9-heptadecanol. The last step was

(a) Transuranic extraction process. 
performed by heating at reflux a mixture of 9-methyl-9-heptadecanol $(10 \mathrm{~g})$, catechol $(4.5 \mathrm{~g})$, and toluenesulfonic acid $(1.4 \mathrm{~g})$ in $100 \mathrm{~mL}$ benzene. The reaction flask was equipped with a Dean Stark trap to remove water from the reaction mixture; removal of water was necessary to drive the reaction to completion. The MONC was purified by liquid chromatography using pentane and methylene chloride as eluents.

\subsection{SOLIDS DISSOLUTION}

The sample of actual CC waste used in this project was received by PNL in July 1983; the sample was taken from Tank 102-AZ. The sample had a total volume of $\sim 32 \mathrm{~mL}$ with $\sim 9 \mathrm{~mL}$ of this volume occupied by settled solids. The volume of solids had not increased since the sample was last examined 7 years previousiy.

The CC waste sample was homogenized by stirring, the slurry $(5 \mathrm{~mL})$ was transferred to a separate vial for dissolution experiments, and $5 \mathrm{~mL}$ of water was added to the slurry. The mixture was stirred for $1.5 \mathrm{~h}$ and allowed to stand overnight. Next the s... ids were filtered, washed with three $5-\mathrm{mL}$ portions of water and then transferred to a vial for dissolution. The filtrate was used for batch tests of various solid sorbents. The solids were slurried with $15 \mathrm{~mL}$ of water, and $0.1 \mathrm{~mL}$ concentrated $\mathrm{HNO}_{3}$ was added to give $\left[\mathrm{HNO}_{3}\right]=0.1 \mathrm{M}$. After this solution was stirred for $2 \mathrm{~h}$ at ambient temperature, it was sampled for analysis. The $\mathrm{HNO}_{3}$ concentration was adjusted to $1.8 \mathrm{M}$ by addition of $1.8 \mathrm{~mL}$ concentrated $\mathrm{HNO}_{3}$. The solution was stirred for $2 \mathrm{~h}$ at ambient temperature, then for $2 \mathrm{~h}$ at $100^{\circ} \mathrm{C}$. This treatment resulted in dissolution of all solids.

\subsection{PREPARATION OF SYNTHETIC CC WASTE}

The synthetic CC waste was prepared according to a procedure described in Lokken et al. (1991). The various components were added in the sequence as numbered in Table 2.1. The procedure was carried out at ambient temperature. After the first addition of sodium carbonate, the $\mathrm{pH}$ was adjusted to 7.7 with sodium hydroxide, then sodium carbonate was added a second time. The mixture 
TABLE 2.1. Composition of the Synthetic CC Waste Supernate

\begin{tabular}{|c|c|c|c|c|}
\hline & Component & $\begin{array}{c}\text { Amount } \\
\text { Added } \\
\end{array}$ & $\begin{array}{c}\text { Target } \\
\text { Concentration, } \underline{M} \\
\end{array}$ & $\begin{array}{c}\text { Concentration } \\
\text { Found, } \underline{M} \\
\end{array}$ \\
\hline 1 & water & $600 \mathrm{~mL}$ & & \\
\hline 2 & $\mathrm{HNO}_{3}$, concentrated & $330 \mathrm{~mL}$ & & \\
\hline 3 & $\mathrm{Al}\left(\mathrm{NO}_{3}\right)_{3} \cdot 9 \mathrm{H}_{2} \mathrm{O}$ & $15.56 \mathrm{~g}$ & 0.024 & 0.022 \\
\hline 4 & $\mathrm{Fe}\left(\mathrm{NO}_{3}\right)_{3} \cdot 9 \mathrm{H}_{2} \mathrm{O}$ & $30.70 \mathrm{~g}$ & 0.038 & 0.00003 \\
\hline 5 & $\mathrm{Ca}\left(\mathrm{NO}_{3}\right)_{2} \cdot 4 \mathrm{H}_{2} \mathrm{O}$ & $11.80 \mathrm{~g}$ & 0.025 & 0.024 \\
\hline 6 & $\mathrm{KNO}_{3}$ & $9.30 \mathrm{~g}$ & 0.046 & 0.042 \\
\hline 7 & $\mathrm{La}\left(\mathrm{NO}_{3}\right)_{3} \cdot 6 \mathrm{H}_{2} \mathrm{O}$ & $0.24 \mathrm{~g}$ & 0.00028 & 0.0002 \\
\hline 8 & $\mathrm{Nd}\left(\mathrm{NO}_{3}\right)_{3} \cdot 5 \mathrm{H}_{2} \mathrm{O}$ & $0.80 \mathrm{~g}$ & 0.00095 & 0.0004 \\
\hline 9 & $\mathrm{Mg}\left(\mathrm{NO}_{3}\right)_{2} \cdot 6 \mathrm{H}_{2} \mathrm{O}$ & $5.64 \mathrm{~g}$ & 0.011 & \\
\hline 10 & $\operatorname{Mn}\left(\mathrm{NO}_{3}\right)_{2}, 50 \%$ solution & $5.16 \mathrm{~g}$ & 0.0072 & \\
\hline 11 & $\mathrm{Ni}\left(\mathrm{NO}_{3}\right)_{2} \cdot 6 \mathrm{H}_{2} \mathrm{O}$ & $4.66 \mathrm{~g}$ & 0.0080 & 0.007 \\
\hline 12 & $\mathrm{Na}_{2} \mathrm{HPO}_{4}$ & $6.24 \mathrm{~g}$ & 0.022 & 0.020 \\
\hline 13 & $\mathrm{NaCl}$ & $4.80 \mathrm{~g}$ & 0.041 & \\
\hline 14 & $\mathrm{Na}_{2} \mathrm{~B}_{4} \mathrm{O}_{7} \cdot 1 \mathrm{OH}_{2} \mathrm{O}$ & $16.02 \mathrm{~g}$ & 0.021 & 0.022 \\
\hline 15 & $\mathrm{Cu}\left(\mathrm{NO}_{3}\right)_{2} \cdot 3 \mathrm{H}_{2} \mathrm{O}$ & $0.20 \mathrm{~g}$ & 0.00041 & 0.0004 \\
\hline 16 & $\left(\mathrm{NH}_{4}\right)_{6} \mathrm{Mo}_{7} \mathrm{O}_{24} \cdot 4 \mathrm{H}_{2} \mathrm{O}$ & $1.58 \mathrm{~g}$ & 0.00064 & 0.00063 \\
\hline 17 & $0.1 \mathrm{M} \mathrm{CsNO}$ & $15 \mathrm{~mL}$ & 0.00075 & 0.00087 \\
\hline 18 & $0.1 \mathrm{M} \mathrm{Sr}\left(\mathrm{NO}_{3}\right)_{2}$ & $15 \mathrm{~mL}$ & 0.00075 & 0.0006 \\
\hline 19 & $\mathrm{Na}_{4}$ EDTA & $23.6 \mathrm{~g}$ & 0.034 & \\
\hline 20 & citric acid, monohydrate & $26.90 \mathrm{~g}$ & 0.064 & \\
\hline 21 & $\mathrm{Na}_{3} \mathrm{HEDTA} \cdot 2 \mathrm{H}_{2} \mathrm{O}$ & $28.72 \mathrm{~g}$ & 0.042 & \\
\hline 22 & $\mathrm{Na}_{3} \mathrm{NTA}$ & $37.6 \mathrm{~g}$ & 0.13 & \\
\hline 23 & $\mathrm{Na}_{2} \mathrm{CO}_{3}$ & $216 \mathrm{~g}$ & & \\
\hline 24 & $50 \% \mathrm{NaOH}$ & $160 \mathrm{~mL}$ & & \\
\hline 25 & $\mathrm{Na}_{2} \mathrm{CO}_{3}$ & $258 \mathrm{~g}$ & 1.2 & \\
\hline 26 & $50 \% \mathrm{NaOH}$ & $32 \mathrm{~mL}$ & & \\
\hline 27 & $\mathrm{NaNO}_{2}$ & $110.4 \mathrm{~g}$ & 0.80 & \\
\hline 28 & $50 \% \mathrm{NaOH}$ & $20 \mathrm{~mL}$ & & \\
\hline
\end{tabular}


was diluted to $2 \mathrm{~L}$ with water, and the final $\mathrm{pH}$ was adjusted to 12.5 by adding sodium hydroxide. The resulting mixture consisted of a pale blue solution and a rust colored precipitate.

\subsection{ACIDIFICATION OF CC WASTE}

To assess the various acid-side separation processes, samples of both the synthetic CC waste and the actual CC waste were acidified with $\mathrm{HNO}_{3}$. The CC waste (solids and supernate) was homogenized by stirring and concentrated $\mathrm{HNO}_{3}$ was added carefully until the $\mathrm{pH} 1$ was reached. It was assumed that all of the hydrolyzable ions had been protonated at $\mathrm{pH} 1$. Concentrated $\mathrm{HNO}_{3}$ was then added to give $\left[\mathrm{HNO}_{3}\right]=1 \underline{M}$. The total acid concentration was detarmined by titration with standard $\mathrm{NaOH}$. The total acid concentration (titrated to $\mathrm{pH} 7$ ) was $1.1 \mathrm{M}$ for the acidified synthetic waste and $1.4 \mathrm{M}$ for the acidified actual $C C$ waste. The reason that the measured total acid concentrations of these solutions were above $1.0 \mathrm{M}$ was likely because hydrolyzable ions were present. The compositions of both the acidified synthetic CC waste and the actual CC waste are compared in Table 2.2. Good agreement was found between many of the waste constituents, especially $\mathrm{Al}, \mathrm{Fe}, \mathrm{La}, \mathrm{Nd}$, and $\mathrm{Ni}$. The amount of $\mathrm{Na}$ in the acidified synthetic waste was somewhat higher than in the actual waste; this was also true for $\mathrm{Cs}$ and $\mathrm{Sr}$.

\subsection{SOLVENT EXTRACTION EXPERIMENTS}

Solvent extraction experiments were performed by mixing an appropriate aqueous solution with the extractant solution of interest. The contacts were accomplished in small vials using a vortex mixer to mix the two phases; contact times were generally one or two minutes in duration. After centrifuging to separate the phases, each phase was sampled for analysis. For tracer experiments, concentrations of ${ }^{241} \mathrm{Am},{ }^{85} \mathrm{Sr}$, and ${ }^{137} \mathrm{Cs}$ were determined by gamma counting; concentrations of ${ }^{99} \mathrm{Tc}$ were determined by liquid scintillation counting. For the extraction of $\mathrm{Sr}$ with $0.05 \mathrm{M} \mathrm{DC18C6}+0.1 \mathrm{M} N \mathrm{NCA}$ in toluene, the solvent was first contacted twice with $6 \mathrm{~mL}$ of $0.33 \mathrm{M} \mathrm{NaOH}+3.33 \mathrm{M} \mathrm{NaNO}$. This procedure converted the neocarboxylic acid into its corresponding sodium salt. For the extraction of TC (alkaline or acidic) with TOAB or TBAN, the 
TABLE 2.2. Composition of Acidified Actual and Synthetic CC Waste

\begin{tabular}{ccc} 
Component & Actual Waste, $\underline{M}$ & Synthetic Waste, $\underline{M}$ \\
\cline { 1 - 3 } $\mathrm{Al}$ & 0.017 & 0.021 \\
$\mathrm{Cd}$ & 0.00023 & \\
$\mathrm{Ce}$ & 0.00080 & \\
$\mathrm{Cr}$ & 0.0012 & \\
$\mathrm{Cs}$ & 0.000043 & $0.00060^{(\mathrm{a})}$ \\
$\mathrm{Cu}$ & 0.00006 & 0.00032 \\
$\mathrm{Fe}$ & 0.030 & 0.027 \\
$\mathrm{~K}$ & 0.0063 & 0.042 \\
$\mathrm{La}$ & 0.00013 & 0.0002 \\
$\mathrm{Mg}$ & 0.00087 & \\
$\mathrm{Mn}$ & 0.0062 & \\
$\mathrm{Mo}$ & 0.00003 & 0.0035 \\
$\mathrm{Na}$ & 2.92 & 4.77 \\
$\mathrm{Nd}$ & 0.00043 & 0.00065 \\
$\mathrm{Ni}$ & 0.0037 & 0.0056 \\
$\mathrm{P}$ & 0.0060 & 0.015 \\
$\mathrm{~Pb}$ & 0.00091 & \\
$\mathrm{Sr}$ & not detected & 0.00053 \\
$\mathrm{Zn}$ & 0.00020 & 0.00002 \\
$\mathrm{Zr}$ & 0.00043 &
\end{tabular}

(a) Estimated from the concentration of $C s$ found in the synthetic CC waste supernate.

solvents were prepared by dissolving the tetraalkylammonium compound in an appropriate diluent. Most solutions were used directly; however, in the case of tricaprylmonomethyl ammonium chloride, the extractant was dissolved in 1-octanol and was then contacted repeatedly with $1 \mathrm{M} \mathrm{HNO}_{3}$ to convert from the chloride to the nitrate form. A portion of the last $1 \mathrm{M} \mathrm{HNO}_{3}$ contact was tested for chloride ion by addition of silver nitrate; no chloride ion was 
found, which indicated complete conversion to the nitrate form. Hereafter, the nitrate form of the tricaprylmonomethly ammonium extractant will be referred to as "TCMA."

Distribution coefficients (D) were calculated as the concentration of a given component in the organic phase divided by the concentration of that component in the aqueous phase.

\subsection{BATCH DISTRIBUTION EXPERIMENTS}

A weighed amount of the sorbent to be tested was contacted by shaking with the test solution. In most cases, the contact period was $-72 \mathrm{~h}$. As a control, a sample of the test solution was placed in a similar bottle (without the sorbent) and agitated in the same way. This feed blank represented the feed solution before contact with the solid exchanger. For tracer experiments, the synthetic CC waste supernate was diluted with two volumes of water and spiked with the appropriate radionuclide $\left({ }^{137} \mathrm{Cs},{ }^{85} \mathrm{Sr},{ }^{239} \mathrm{Pu},{ }^{99} \mathrm{Tc}\right.$, or $\left.{ }^{241} \mathrm{Am}\right)$. For experiments with the actual CC waste, the supernatant solution was diluted with an equal volume of water before contact with the sorbent of

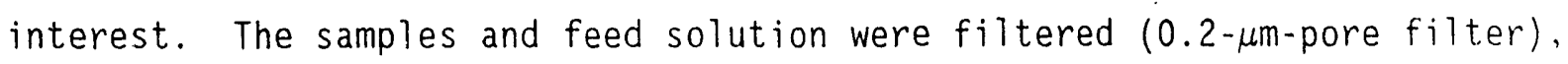
and the concentration of the radionuclide of interest was determined by gamma counting $\left({ }^{137} \mathrm{Cs}\right.$ and $\left.{ }^{85} \mathrm{Sr}\right)$ or liquid scintillation counting $\left({ }^{239} \mathrm{Pu},{ }^{99} \mathrm{Tc}\right.$, and $\left.{ }^{241} \mathrm{Am}\right)$. Batch distribution ratios, $R_{d}$, were calculated as the concentration of the radionuclide of interest in the solid sorbent (quantity/g of sorbent) divided by the concentration in solution (quantity/mL of solution).

\subsection{EVALUATION OF SI-L FOR REMOVAL OF CS}

A chromatographic material ( $\mathrm{Si}-\mathrm{L}$ ) consisting of a macrocycle bound to a silica gel support was tested for removal of $\mathrm{Cs}$ from acid solution. Two grams of $\mathrm{Si-L}(\mathrm{a})$ was wet-packed into a column 10.5-mm ID; the bed volume was $4 \mathrm{~mL}$. The column was washed with $20 \mathrm{~mL}$ of $5 \underline{\mathrm{M} \mathrm{HNO}} \mathrm{HN}_{3}$, then with $5 \mathrm{~mL}$ of $1.0 \mathrm{M} \mathrm{\textrm {HNO } _ { 3 }}$. The feed solution was $1.0 \mathrm{M} \mathrm{HNO}_{3}$ spiked with ${ }^{137} \mathrm{Cs}(\sim 0.1 \mu \mathrm{Ci} / \mathrm{mL})$. This

(a) This particular sample of $\mathrm{Si}-\mathrm{L}$ had been previously used in experiments at PNL by Camaioni et al. (1991). In that experiment, the Cs was eluted from the $\mathrm{Si}-\mathrm{L}$ with $0.01 \mathrm{M} \mathrm{HNO}_{3}$. 
solution was passed through the column. One-milliliter fractions of the effluent were taken, and the ${ }^{137} \mathrm{Cs}$ activity in each was determined by gamma counting using a sodium iodide detector.

\subsection{MACRORETICULAR SUPPORT IMPREGNATED WITH SODIUM NICKEL FERROCYANIDE (FECN- XAD-4) FOR THE REMOVAL OF CS}

Twenty-five milliliters of $0.5 \mathrm{M} \mathrm{Na}{ }_{4} \mathrm{Fe}(\mathrm{CN})_{6}$ (12.5 mmole) was added to a slurry of Amberlite ${ }^{\circledR}$ XD-4 beads $(10 \mathrm{~g})$ in $25 \mathrm{~mL}$ of water. After the mixture was stirred for $15 \mathrm{~min}, 12.5 \mathrm{~mL}$ of $1.0 \mathrm{M} \mathrm{Ni}\left(\mathrm{NO}_{3}\right)_{2}$ (12.5 mmole) was added, and the mixture was stirred for another $15 \mathrm{~min}$. The beads were filtered, washed with three $10-\mathrm{mL}$ portions of $1.0 \mathrm{M} \mathrm{HNO}_{3}$ and then with three $10-\mathrm{mL}$ portions of water, and dried in vacuo. This sorbent material will be referred to as FeCN-XAD-4.

Batch distribution measurements were taken for FeCN-XAD-4. First, $0.1 \mathrm{~g}$ of FeCN-XAD-4 was shaken with $4 \mathrm{~mL}$ of the appropriate test solution, which had been spiked with ${ }^{137} \mathrm{Cs}$. Then after $2 \mathrm{~h}$, a sample of the solution was withdrawn for gamma counting. Two experiments were then performed to assess the efficiency of $\mathrm{FeCN}-\mathrm{XAD}-4$ in removing ${ }^{137} \mathrm{C} S$ from acidic solution. The feed solution in one experiment was $1.0 \mathrm{M} \mathrm{HNO}_{3}$, while the feed solution in the other was acidified synthetic CC waste $\left(1.1 \mathrm{M} \mathrm{H}^{+}\right)$; both solutions were spiked with ${ }^{137} \mathrm{Cs}$. The procedure was the same for both experiments. FeCN-XAD-4 was wet-packed into a column 10.5-mm ID; the bed volume was 4 to $7 \mathrm{~mL}$. The appropriate feed solution was passed through the column, and 1-mL fractions were collected for gamma counting.

\subsection{PRECIPITATION OF CS WITH SODIUM PHOSPHOTUNGSTATE}

An amount of $22 \mu \mathrm{L}$ of $0.1 \underline{\mathrm{M} \mathrm{Na}} \mathrm{PW}_{12} \mathrm{O}_{40}$ was added to $8 \mathrm{~mL}$ of acidified $\left(1.1 \mathrm{M} \mathrm{H} \mathrm{H}^{+}\right)$synthetic CC waste spiked with tracer ${ }^{137} \mathrm{Cs}$. After the mixture was stirred for $\sim 16 \mathrm{~h}$, the amount of $C s$ remaining in solution was determined by gamma counting. An additional $20 \mu \mathrm{L}$ of $0.1 \mathrm{M} \mathrm{Na}_{3} \mathrm{PW}_{12} \mathrm{O}_{40}$ was added. This solution was then stirred for an additional $16 \mathrm{~h}$. The $\mathrm{Cs}$ remaining in solution was again determined by gamma counting. 
Eight milliliters of acidified $\left(1.4 \mathrm{M} \mathrm{H}^{+}\right)$actual $\mathrm{CC}$ waste was treated with $\mathrm{Na}_{3} \mathrm{PW}_{12} \mathrm{O}_{40}$ in the following successive steps: 1) $20 \mu \mathrm{L} 0.1 \mathrm{M} \mathrm{Na}_{3} \mathrm{PW}_{12} \mathrm{O}_{48}$, contact time $16 \mathrm{~h}$; 2) $20 \mu \mathrm{L} 0.1 \mathrm{M} \mathrm{Na}_{3} \mathrm{PW}_{12} \mathrm{O}_{40}$, contact time $2 \mathrm{~h}$; 3) $200 \mu \mathrm{L} 0.1 \mathrm{M}$ $\mathrm{Na}_{3} \mathrm{PW}_{12} \mathrm{O}_{49}$, contact time $\left.24 \mathrm{~h} ; 4\right) 200 \mu \mathrm{L} 0.1 \mathrm{M} \mathrm{Na}_{3} \mathrm{PW}_{12} \mathrm{O}_{49}$, contact time $1 \mathrm{~h}$. The concentration of ${ }^{137} \mathrm{Cs}$ remaining in solution after each step was determined by gamma energy analysis. 


\subsection{RESULTS AND DISCUSSION}

\subsection{CHARACTERIZATION OF CC WASTE SAMPLES}

The supernatant solutions from the syninetic CC waste and the actual CC waste samples were analyzed for metal cations, total organic carbon (TOC), and total carbon (TC). The compositions of synthetic and actual CC supernates are compared in Table 3.1. This table presents the difficulties encountered in CC waste simulation. Iron is a major component of the actual CC waste supernate, but when the synthetic CC waste was prepared, most of the Fe precipitated, as evidenced by the rust-colored precipitate formed and the low Fe concentration in the supernate $\left(2 \therefore i 0^{-5} \mathrm{M}\right)$. The TOC content of the synthetic waste was much less than in the actual CC waste solution. This may account for the precipitation of most of the $\mathrm{Fe}$. The concentrations of other components in the synthetic CC waste deviated considerably from those found in the actual waste; however, the recipe used to prepare the synthetic CC waste was based on the analysis of a different CC waste sample (from Tank 107-AN) (Lokken et al. 1991). Certain components (e.g., $\mathrm{Cr}, \mathrm{Cd}$, and $\mathrm{Pb}$ ) were omitted from the synthetic CC waste to allow easier disposal of the material upon completion of the project.

The current composition data for the actual waste were generally similar to the 1983 data from the same sample, especially for components present at $\geq 0.01 \mathrm{M}$. Exceptions were $\mathrm{Al}$ and $\mathrm{Mn}$ because only $67 \%$ and $47 \%$, respectively, were found in the current data compared to the 1983 data.

The radionuclide content of the actual CC waste supernate is summarized in Table 3.2. The TRU content of $1000 \mathrm{nCi} / \mathrm{g}$ (solution density is $1.36 \mathrm{~g} / \mathrm{mL}$ ) is 10 times the NRC Class C LLW criterion and 100 times the Class A LLW 1 imit. The ${ }^{137} \mathrm{Cs}$ content is 260 times the Class A LLW limit of $1 \mu \mathrm{Ci} / \mathrm{mL}$. The contents reported here for ${ }^{241} \mathrm{Am},{ }^{60} \mathrm{Co},{ }^{137} \mathrm{Cs}$, and ${ }^{154,155} \mathrm{Eu}$ agree closely (when corrected for decay) with those measured in this sample in 1983 . However, the current $\mathrm{Pu}$ value is $-60 \%$ higher than that reported earlier; it is not known whether this difference indicates some changing chemistry within the sample. 
TABLE 3.1. Composition of Actual and Synthetic CC Waste Supernates

\begin{tabular}{|c|c|c|c|}
\hline \multirow[b]{2}{*}{ Component } & \multicolumn{2}{|c|}{ Actual Waste, mol/L } & \multirow[b]{2}{*}{$\begin{array}{c}\text { Synthetic } \\
\text { Waste, mol/L }\end{array}$} \\
\hline & $\begin{array}{l}\text { This } \\
\text { Work }\end{array}$ & $\begin{array}{l}1983 \\
\text { Data } \\
\end{array}$ & \\
\hline Al & 0.012 & 0.018 & 0.022 \\
\hline As & 0.00023 & & \\
\hline B & 0.0011 & & 0.089 \\
\hline $\mathrm{Ba}$ & 0.00012 & 0.00009 & \\
\hline $\mathrm{Ca}$ & 0.015 & 0.016 & 0.024 \\
\hline $\mathrm{Cd}$ & 0.00034 & & \\
\hline $\mathrm{Ce}$ & 0.00067 & & \\
\hline $\mathrm{Cr}$ & 0.0030 & 0.0028 & \\
\hline $\mathrm{Cu}$ & 0.00056 & & 0.00039 \\
\hline $\mathrm{Fe}$ & 0.077 & 0.069 & 0.00002 \\
\hline$k$ & 0.020 & 0.017 & 0.042 \\
\hline La & 0.00040 & 0.00031 & 0.00017 \\
\hline $\mathrm{Mg}$ & 0.0010 & 0.0014 & \\
\hline $\mathrm{Mn}$ & 0.017 & 0.036 & \\
\hline Mo & 0.00014 & 0.00011 & 0.0044 \\
\hline $\mathrm{Na}$ & 7.6 & 7.6 & 6 \\
\hline $\mathrm{Nd}$ & 0.0013 & 0.00056 & 0.0004 \\
\hline $\mathrm{Ni}$ & 0.010 & 0.010 & 0.0071 \\
\hline$P$ & 0.015 & & 0.020 \\
\hline $\mathrm{Pb}$ & 0.0026 & & \\
\hline $\operatorname{Re}$ & 0.0029 & & \\
\hline $\mathrm{Ru}$ & 0.00031 & & \\
\hline$S i$ & 0.00082 & & \\
\hline$s r$ & 0.00006 & 0.00006 & 0.00060 \\
\hline Th & 0.00024 & & \\
\hline U & 0.0010 & & \\
\hline $\mathrm{Zn}$ & 0.00072 & 0.0017 & 0.00002 \\
\hline $\mathrm{Zr}$ & 0.0014 & 0.0011 & \\
\hline TC & 6.2 & & 2.03 \\
\hline TOC & 5.2 & & 1.07 \\
\hline TIC & 1 & & 0.96 \\
\hline
\end{tabular}


TABLE 3.2. Radionuclide Content of CC Waste Supernate

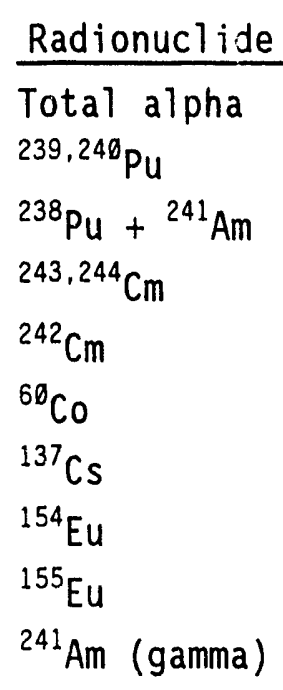

\begin{tabular}{|c|c|}
\hline \multicolumn{2}{|c|}{$\mathrm{nCi} / \mathrm{mL}$} \\
\hline This Work & 1983 \\
\hline 1360 & not reported \\
\hline 160 & 103 \\
\hline 1130 & 1,080 \\
\hline 60 & not reported \\
\hline 7 & not reported \\
\hline 510 & $470^{(a)}$ \\
\hline 200,000 & $224,000^{(a)}$ \\
\hline 3,230 & $4,080^{(a)}$ \\
\hline 3810 & not reported \\
\hline 1590 & not reported \\
\hline
\end{tabular}

(a) Corrected for decay.

\subsection{SOLIDS DISSOLUTION}

When a slurry of the actual CC waste was diluted with an equal vo? ume of water (and stirred for $1.5 \mathrm{~h}$ ), the concentrations of the major components in the resulting supernatant solution were as expected for a one-to-one dilution; this indicates that the amounts of such components that had dissolved from the solids were minimal at most. However, the concentrations of certain minor components in the supernatant solution were greater than expected for a oneto-one dilution. These components are listed in Table 3.3 along with their respective concentrations. In the cases of $\mathrm{As}, \mathrm{Ti}$, and $\mathrm{V}$, dilution with one volume of water resulted in complete dissolution; none of these components were observed in the solid material remaining. Significant amounts of $\mathrm{Mg}$ and $\mathrm{Sr}$ remained in the solid material. No TRU elements were dissolved upon addition of water.

The CC solids were separated from the supernate by filtration and were washed with water. Analysis of the wash solution revealed that additional quantities of $\mathrm{Al}$ and $\mathrm{Sr}$ had been dissolved by washing the solids with water. 
TABLE 3.3. Comporients of Actual CC Solids That Dissolved by Dilution with Water

\begin{tabular}{|c|c|c|c|}
\hline \multirow[b]{2}{*}{ Component } & \\
\hline & Supernate, $\underline{M}$ & $\begin{array}{l}\text { Expected } \\
\text { for } 1-\text { to-1 } \\
\text { Dilution, M }\end{array}$ & $\begin{array}{c}\text { Found After } \\
1-\text { to-1 } \\
\text { Dilution, }\end{array}$ \\
\hline As & 0.00023 & 0.00012 & 0.00028 \\
\hline $\mathrm{Mg}$ & 0.0010 & 0.0005 & 0.0007 \\
\hline$S r$ & 0.00006 & 0.00003 & 0.00017 \\
\hline $\mathrm{Ti}$ & 0.0 & 0.0 & 0.00063 \\
\hline$v$ & 0.0 & 0.0 & 0.0047 \\
\hline
\end{tabular}

The ratios of grams of $\mathrm{Al}$ or $\mathrm{Sr}$ to grams of $\mathrm{Na}$ in the wash solution ( $\mathrm{g} \mathrm{Al} / \mathrm{g} \mathrm{Na}=0.0044, \mathrm{~g} \mathrm{Sr} / \mathrm{g} \mathrm{Na}=0.00068$ ) were significantly greater than in the filtered supernate solution ( $\mathrm{g} \mathrm{Al} / \mathrm{g} \mathrm{Na}=0.0018, \mathrm{~g} \mathrm{Sr} / \mathrm{g} \mathrm{Na}=0.00016)$. For all other components, the rai io of $\mathrm{g}$ component/g $\mathrm{Na}$ was the same in the wash solution and the filtered supernate.

The washed solids were treated successively with $0.1 \mathrm{M} \mathrm{HNO}_{3}, 1.8 \mathrm{M} \mathrm{HNO}_{3}$ at ambient temperature, and $1.8 \mathrm{M} \mathrm{HNO}_{3}$ at $100^{\circ} \mathrm{C}$. After the final treatment, all solids had dissolved. The percentage of each component in the solids found in solution during the various dissolution steps are listed in Table 3.4. For most of the components, greater than $80 \%$ dissolution was obtained in $0.1 \mathrm{M} \mathrm{HNO}_{3}$; exceptions to this were $\mathrm{Fe}, \mathrm{Mn}$, and $\mathrm{Pb}$. Upon raising the $\mathrm{HNO}_{3}$ concentration to $1.8 \mathrm{M}$, all of the components except $\mathrm{Pb}$ dissolved to $95 \%$ or greater. Heating at $100^{\circ} \mathrm{C}$ dissolved the remaining $\mathrm{Pb}$.

Listed in Table 3.5 are the amounts of each actual CC waste component found in a) the supernatant solution after one-to-one dilution with water, b) the solution obtained from washing of the solids, and c) the final dissolved sludge solution. Also listed are the grams of each element per gram of CC waste (slurried), and the percentage of each element found in the washed solid portion of the waste. As expected, the quantity of $\mathrm{Na}$ in this waste 
TABLE 3.4. Summary of Actual CC Solids Dissolution

\begin{tabular}{|c|c|c|c|}
\hline \multirow[b]{2}{*}{ Component } & \multicolumn{3}{|c|}{ Percentage } \\
\hline & $\begin{array}{l}0.1 \mathrm{M} \\
\mathrm{HNO}_{3}\end{array}$ & $\begin{array}{r}1.8 \mathrm{M} \mathrm{HNO}_{3} \\
\text { (ambient } \\
\text { temperature) } \\
\end{array}$ & $\begin{array}{c}1.8 \mathrm{M} \mathrm{HNO}_{3} \\
\left(100^{\circ} \mathrm{C}\right) \\
\end{array}$ \\
\hline Al & 87 & 96 & 100 \\
\hline $\mathrm{Ca}$ & 90 & 98 & 100 \\
\hline $\mathrm{Cr}$ & 88 & 100 & 100 \\
\hline $\mathrm{Fe}$ & 15 & 95 & 100 \\
\hline $\mathrm{Mg}$ & 90 & 97 & 100 \\
\hline$M n$ & 49 & 100 & 100 \\
\hline $\mathrm{Na}$ & 95 & 96 & 100 \\
\hline $\mathrm{Pb}$ & 0 & 0 & 100 \\
\hline$S r$ & 97 & 100 & 100 \\
\hline
\end{tabular}

dwarfs the amount of other elements, (a) with $\mathrm{Na}$ accounting for $15 \%$ of the total mass of the CC waste. The next most abundant elements are $\mathrm{Fe}(0.4 \%)$ and Al $(0.2 \%)$. The most abundant elements found in the washed solid portion of the waste are $\mathrm{AT}$ and $\mathrm{Na}$.

These results suggest that $\mathrm{CC}$ solids readily dissolve in dilute $\mathrm{HNO}_{3}$. However, it must be stressed that the CC solids used in this study may differ considerably from CC sludge stored in underground tanks at Hanford. The solids present in the $C C$ waste sample used in this study are believed to have formed after the liquid sample had been removed from Tank 102-AZ; the solids presumably precipitated as the sample cooled (or aged). Thus, further investigations regarding the dissolution of $C C$ sludge need to be performed using solids actually removed from the tanks.

(a) Only the elements determined by inductively coupled plasma-atomic emission spectroscopy are considered, i.e., elements such as carbon also contribute greatly to the mass of the CC waste, but are not included in Table i.5. 
IABLE 3.5. Quantities of Actual CC Waste Components

Amount of Waste Components, $\mathrm{g}$

\begin{tabular}{|c|c|c|c|c|c|}
\hline Elements & $\begin{array}{c}\text { Diluted } \\
\text { Supernate } \\
\end{array}$ & $\begin{array}{c}\text { Wash } \\
\text { Solution }\end{array}$ & $\begin{array}{l}\text { Dissolved } \\
\text { Sludge } \\
\text { Solution } \\
\end{array}$ & $\begin{array}{c}\text { Per } \\
\text { Gram CC } \\
\text { Waste } \\
\end{array}$ & $\begin{array}{l}\text { Washed CC } \\
\text { Solids, \% }\end{array}$ \\
\hline Al & 0.00164 & 0.00046 & 0.0126 & 0.00216 & 86 \\
\hline As & 0.00021 & 0 & 0 & 0.00003 & 0 \\
\hline B & 0.00006 & 0 & 0 & 0.00001 & 0 \\
\hline $\mathrm{Ba}$ & 0.00009 & 0.00001 & 0.00001 & 0.00002 & 11 \\
\hline $\mathrm{Ca}$ & 0.00355 & 0.00040 & 0.00022 & 0.00061 & 5 \\
\hline $\mathrm{Cd}$ & 0.00020 & 0 & 0 & 0.00003 & 0 \\
\hline $\mathrm{Ce}$ & 0.00042 & 0 & 0 & 0.00006 & 0 \\
\hline $\mathrm{Cr}$ & 0.00081 & 0.00009 & 0.00006 & 0.00014 & 7 \\
\hline $\mathrm{Cu}$ & 0.00018 & 0.00002 & 0 & 0.00003 & 0 \\
\hline $\mathrm{Fe}$ & 0.02253 & 0.00248 & 0.00167 & 0.00392 & 6 \\
\hline$k$ & 0.00391 & 0 & 0 & 0.00057 & 0 \\
\hline La & 0.00028 & 0 & 0 & 0.00004 & 0 \\
\hline $\mathrm{Mg}$ & 0.00016 & 0.00003 & 0.00016 & 0.00005 & 47 \\
\hline $\mathrm{Mn}$ & 0.00479 & 0.00050 & 0.00002 & 0.00078 & 0 \\
\hline Mo & 0.00007 & 0 & 0 & 0.00001 & 0 \\
\hline $\mathrm{Na}$ & 0.915 & 0.105 & 0.0135 & 0.152 & 1 \\
\hline $\mathrm{Nd}$ & 0.00098 & 0 & 0 & 0.00014 & 0 \\
\hline $\mathrm{Ni}$ & 0.00314 & 0.00033 & 0 & 0.00051 & 0 \\
\hline$P$ & 0.00248 & 0 & 0 & 0.00036 & 0 \\
\hline $\mathrm{Pb}$ & 0.00240 & 0.00026 & 0.0011 & 0.00055 & 28 \\
\hline $\operatorname{Re}$ & 0.00278 & 0.00026 & 0 & 0.00045 & 0 \\
\hline$R u$ & 0.00020 & 0 & 0 & 0.00003 & 0 \\
\hline $\mathrm{Si}$ & 0.00011 & 0 & 0 & 0.00002 & 0 \\
\hline $\mathrm{Sr}$ & 0.00014 & 0.00007 & 0.00018 & 0.00006 & 45 \\
\hline Th & 0.00023 & 0 & 0 & 0.00003 & 0 \\
\hline $\mathrm{Ti}$ & 0.00030 & 0 & 0 & 0.00004 & 0 \\
\hline U & 0.00119 & 0 & 0 & 0.00017 & 0 \\
\hline v & 0.00241 & 0 & 0 & 0.00036 & 0 \\
\hline $\mathrm{Zn}$ & 0.00026 & 0 & 0 & 0.00004 & 0 \\
\hline $\mathrm{Zr}$ & 0.00023 & 0 & 0 & 0.00003 & 0 \\
\hline
\end{tabular}




\subsection{SEPARATIONS FROM ACIDIC SOLUTION}

Various methods were evaluated for the separation of ${ }^{137} \mathrm{Cs},{ }^{99} \mathrm{Tc}$, and ${ }^{90} \mathrm{Sr}$ from $\mathrm{HNO}_{3}$ solutions. Three methods showed promise for the separation of ${ }^{137} \mathrm{Cs}$ : 1) extraction with di-t-butylbenzo-21-crown-7 (DtBB21i7) + HDNNS, 2) sorption on $\mathrm{FeCN}-\mathrm{XAD}-4$, and 3) precipitation with phosphotungstate. Extraction of ${ }^{137} \mathrm{Cs}$ with DtBB21C7 + HDNNS and sorption of ${ }^{137} \mathrm{Cs}$ on $\mathrm{FeCN}-\mathrm{XAD}-4$ were sensitive to high $\mathrm{Na}$ concentrations; thus, these methods would be useful only in a case where a washed sludge was dissolved for processing. Precipitation with phosphotungstate can be performed in the presence of large amounts of $\mathrm{Na}$, but a batch precipitation process such as this would not be as favorable as a continuous process for $C s$ removal. Extraction of Tc with tetraalkylammonium salts showed great promise, but a suitable method of stripping the Tc from the solvent needs to be developed. A screening of the SREX process for extraction of $\mathrm{Sr}$ from acidified $\mathrm{CC}$ waste indicated this method is suitable for removal of Sr from CC waste.

\subsubsection{Separation of Cs from Acidic Solution}

$\underline{S i-L}$. The ability of $S i-L$ to remove trace quantities of $C s$ from acidic solution was evaluated. A feed solution consisting of $1.0 \mathrm{M} \mathrm{HNO}_{3}$ spiked with ${ }^{137} C S$ was passed through a column containing the $S i-L$. The amount of ${ }^{137} C S$ in the effluent was monitored by gamma-counting techniques. The concentration of ${ }^{137} \mathrm{Cs}$ in the effluent began to rise sharply after 1.5 bed volumes of feed had been passed through the column (Figure 3.1). These data suggest that the Si-L used in this experiment is not suitable for removal of trace quantities of $C s$ from $1.0 \mathrm{M} \mathrm{HNO}_{3}$ solution. (a)

FeCN-XAD-4. Ferrocyanide salts have been soried onto macroreticular supports, and such materials have demonstrated an affinity for Cs (Hendrickson and Riel 1975). A sample of Amberlite ${ }^{(B)}$ XAD-4 was impregnated with sodium nickel ferrocyanide. The affinity of this material (FeCN-XAD-4) for CS was

(a) The $\mathrm{Si}-\mathrm{L}$ used in this experiment was not virgin material; it had been used in a previous experiment carried out at PNL by Camaioni et al. (1991). It is possible that the properties of this material were altered in this previous experiment, decreasing its affinity for Cs. It might be worthwhile to repeat this test with virgin $S i-L$. 


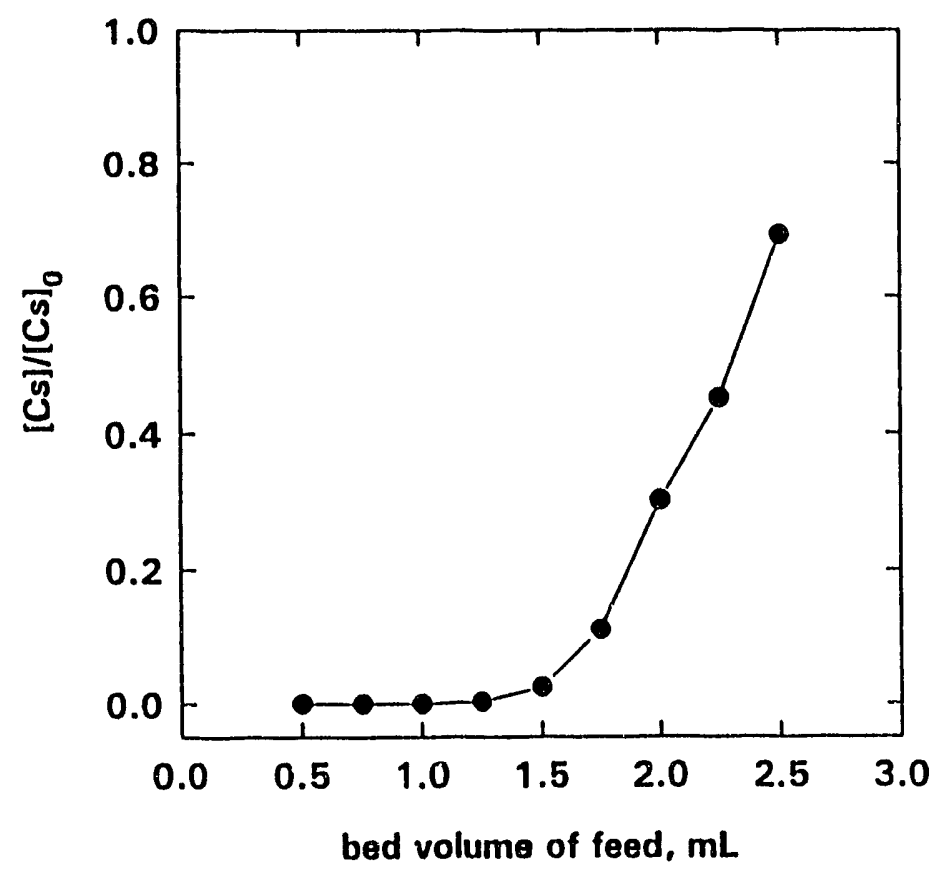

FIGURE 3.1. Breakthrough Curve for Sorption of CS on Si-L

evaluated by batch distribution methods at ambient temperature. The affinity for Cs from $1.0 \mathrm{M} \mathrm{HNO} \mathrm{H}_{3}$ solution was initially very high $\left(R_{d}=8500 \mathrm{~mL} \cdot \mathrm{g} \cdot\right)$, but decreased as the sorbent was aged under dry conditions $\left(R_{d}=240 \mathrm{~mL} \cdot \mathrm{g}^{-\mathrm{i}}\right.$ after 4 weeks). Two columns were prepared with FeCN-XAD-4. Through one of these columns was passed a $1.0 \mathrm{M} \mathrm{HNO}$ solucion spiked with ${ }^{137} \mathrm{Cs}$; through the other, acidified $\left(1.1 \mathrm{M} \mathrm{H}^{+}\right.$) synthetic $C C$ waste (also spiked with ${ }^{137} \mathrm{Cs}$ ). The results are summarized in Figure 3.2. In the case of the $1.0 \mathrm{M} \mathrm{HNO}_{3}$ solution, 6 bed volumes of feed were passed through the column before Cs began to break through. However, breakthrough for the synthetic waste occurred after 0.5 bed volume of feed had passed through the column, suggesting the $\mathrm{FeCN}-\mathrm{XAD}-4$ would not be suitable for removal of ${ }^{137} \mathrm{Cs}$ from directly acidified $C \mathrm{C}$ waste.

Because the concentration of $C_{S}$ in the synthetic $C C$ waste was several orders of magnitude greater than in the spiked $1.0 \mathrm{M} \mathrm{HNO}_{3}$ solution, the breakthrough data (Figure 3.2) for these two solutions could not be compared directly; that is, the early breakthrough for the synthetic CC waste might have occurred because the column was saturated with Cs. However, interference 


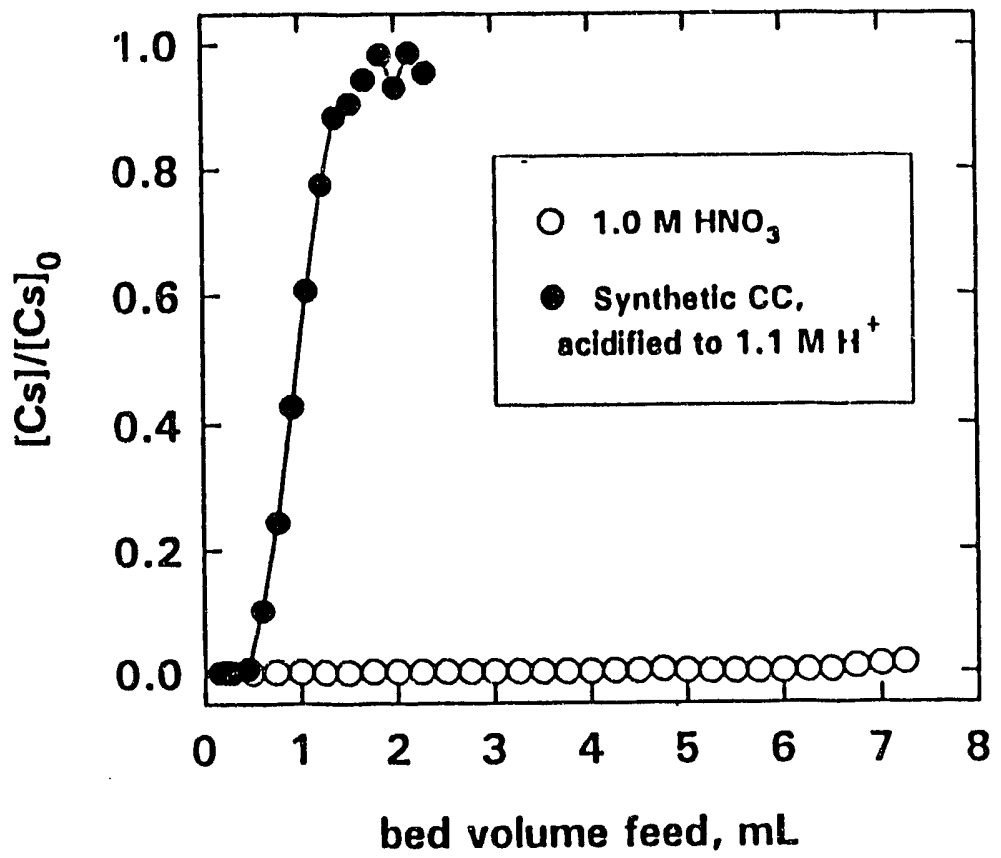

FIGURE 3.2. Breakthrough Curve for the Sorption of Cs on FeCN-XAD-4

by sodium ion was thought to be a more plausible explanation. To assess whether large amounts of $\mathrm{Na}$ contributed to the poor performance of FeCN-XAD-4 for the synthetic CC waste, the affinity of FeCN-XAD-4 for $C S$ from $1.0 \mathrm{M} \mathrm{HNO}$ solution in the presence $\left(3.5 \mathrm{M} \mathrm{NaNO}_{3}\right)$ and absence of $\mathrm{Na}$ was evaluated by batch distribution measurements. When $3.5 \mathrm{M}$ Na was present, the $R_{d}$ for $C s$ was $72 \mathrm{~mL} \cdot \mathrm{g}^{-1}$, whereas when no $\mathrm{Na}$ was present a much higher $R_{d}\left(240 \mathrm{~mL} \cdot \mathrm{g}^{-1}\right)$ was observed. Thus, the presence of large quantities of $\mathrm{Na}$ suppressed the removal of $\mathrm{CS}$ by FeCN-XAD-4.

The results presented here suggest that a sorbent consisting of sodium nickel ferrocyanide on a macroreticular support would not be suitable for removal of ${ }^{137} \mathrm{Cs}$ from directly acidified CC waste (Option III, Figure 1.1) because of the high sodium ion concentration that would be present. However, if the CC supernate is separated from the sludge, and the sludge is washed before dissolution, the concentration of $\mathrm{Na}$ in the dissolved sludge solution is expected to be quite low. If the amount of ${ }^{137} \mathrm{Cs}$ remaining in the sludge is enough to require removal, a sorbent such as FeCN-XAD-4 might be suitable. 
Extraction of CS with DtBB21C7 and HDNNS. MCDowell et al. (1986) have reported the synergistic extraction of $C s$ from acidic solutions with dibenzo21-crown-7 (DB21C7) and didodecylnaphthalenesulfonic acid (HDDNS). The possibility of using such a system to extract $C s$ from acidified $C C$ waste was explored. This study employed DtBB21C7 in place of DB21C7 (because DtBB21C7 has better solubility characteristics), and HDNNS instead of HDDNS. (a) The results are summarized in Figure 3.3 and Table 3.6. These data indicate that the extraction is highly dependent on the diluent; higher Cs distribution coefficiants are obtained when toluene rather than 1-octanol is used as diluent. Because of its low flash point, toluene is not a desirable diluent for a large scale process. However, the Cs distribution coefficients obtained with an extractant consisting of $0.05 \underline{M}$ DtBB21C7 $+0.05 \underline{M}$ HDNNS in toluene are

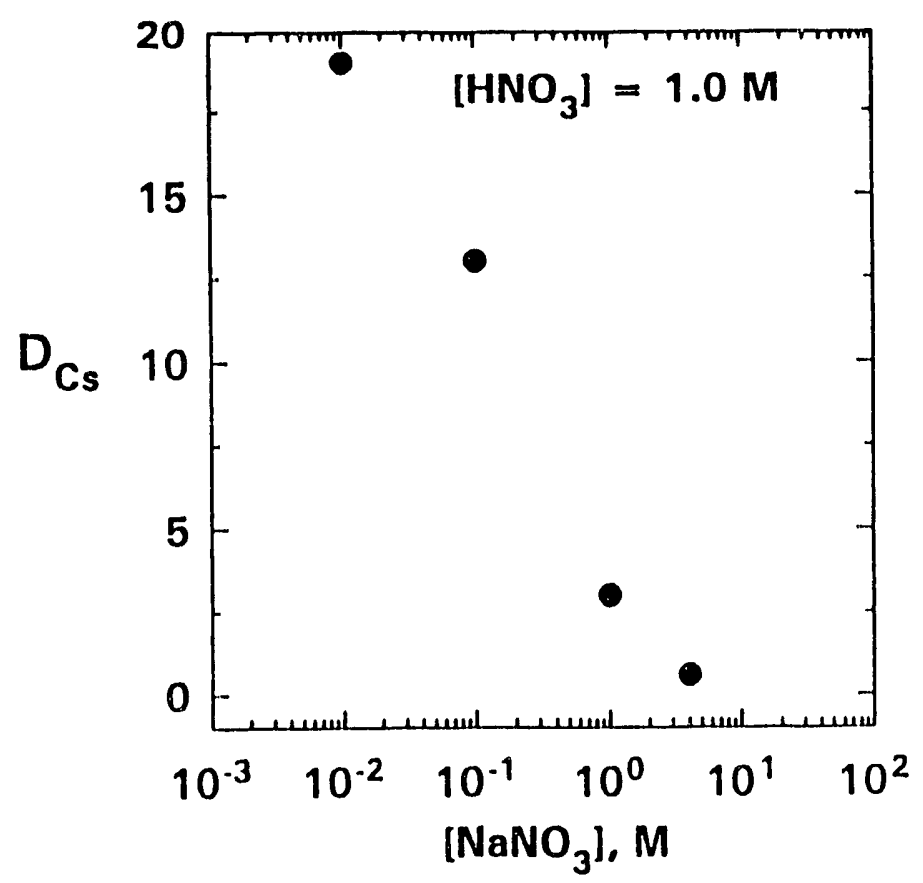

FIGURE 3.3. Extraction of $C S$ with $0.05 \underline{M}$ DtBB21C7 and $0.05 \underline{M}$ HDNNS in Toluene. Distribution coefficient for $C S$ as a function of $\mathrm{NaNO}_{3}$ concentration.

(a) The properties of HDNNS are very similar to those of HDDNS. Because of the availability of HDNivS, this extractant was chosen for this study. 
TABLE 3.6. Extraction of $\mathrm{CS}$ with DtBB21C7 and HDNNS

\begin{tabular}{|c|c|c|c|c|}
\hline \multirow{2}{*}{$\begin{array}{c}\text { Aqueous Phase } \\
\text { (spiked with }{ }^{137} \mathrm{Cs} \text { ) }\end{array}$} & \multicolumn{4}{|c|}{ Organic Phase } \\
\hline & [DtBB21C7] & [HDNNS] & Diluent & $D_{c s}$ \\
\hline $1.0 \mathrm{M} \mathrm{HNO}_{3}$ & 0.1 & 0.0 & 1-octanol & 0.21 \\
\hline $1.0 \mathrm{M} \mathrm{HNO}_{3}$ & 0.075 & 0.075 & 1-octanol & 0.25 \\
\hline $1.0 \underline{\mathrm{M} \mathrm{HNO}} 3+5 \underline{\mathrm{M} \mathrm{NaNO}} 3$ & 0.075 & 0.075 & 1 -octanol & 0.17 \\
\hline $0.1 \mathrm{M} \mathrm{HNO}$ & 0.075 & 0.075 & 1 -octanol & 2 \\
\hline $0.01 \mathrm{M} \mathrm{HNO}$ & 0.075 & 0.075 & 1-octanol & 18 \\
\hline $1.0 \mathrm{M} \mathrm{HNO}$ & 0.05 & 0.05 & toluene & 14 \\
\hline Acidified $\left(1.1 \mathrm{M} \mathrm{HNO}_{3}\right)$ & 0.05 & 0.05 & toluene & 0.3 \\
\hline $1.0 \underline{\mathrm{M} \mathrm{HNO}}{ }_{3}+0.01 \mathrm{M} \mathrm{NaNO}$ & 0.05 & 0.05 & toluene & 19 \\
\hline $1.0 \underline{\mathrm{M}} \mathrm{HNO}_{3}+0.1 \underline{\mathrm{M} \mathrm{NaNO}} \mathrm{N}_{3}$ & 0.05 & 0.05 & toluene & 13 \\
\hline $1.0 \mathrm{M} \mathrm{HNO}{ }_{3}+1 \mathrm{M} \mathrm{NaNO}$ & 0.05 & 0.05 & toluene & 3 \\
\hline $1.0 \mathrm{M} \mathrm{HNO}{ }_{3}+4 \mathrm{M} \mathrm{NaNO}$ & 0.05 & 0.05 & toluene & 0.6 \\
\hline
\end{tabular}

among the highest reported for $1.0 \mathrm{M} \mathrm{HNO}$ (when $\left[\mathrm{Na}^{+}\right]$is $10 \mathrm{w}$ ). Thus, further investigation of this type of system is warranted; identification of a suitable diluent is required.

The data presented in Figure 3.3 indicate that the extraction of Cs with DtBB21C7 and HDNNS is suppressed by high concentrations of sodium. Removal of the bulk $\mathrm{Na}$ by sludge washing before acid dissolution would be required if such extractants are to be used to separate ${ }^{137} \mathrm{Cs}$ from acidified CC waste (assuming removal of ${ }^{137} \mathrm{Cs}$ is required after sludge washing).

Precipitation of $C_{S}$ with Sodium Phosphotungstate. As part of this study, precipitation with phosphotungstate was investigated as a means of removing $C s$ from acidified $C C$ waste. When a solution of ${ }^{137} \mathrm{Cs}$-spiked acidified synthetic CC waste $\left(1.1 \mathrm{M} \mathrm{H}^{+} ; 5.5 \times 10^{-6}\right.$ mole $\left.\mathrm{Cs}\right)$ was treated with $\mathrm{Na}_{3} \mathrm{PW}_{12} \mathrm{O}_{40}\left(2.2 \times 10^{-6}\right.$ mole $), 98.87 \%$ of the $\mathrm{CS}$ present precipitated giving a $D F^{(a)}$ of 88.7 . A second strike with $2.0 \times 10^{-6}$ mole $\mathrm{Na}_{3} \mathrm{PW}_{12} \mathrm{O}_{40}$ resulted in

(a) Decontamination factor (DF) is the concentration of a given component in the feed divided by the concentration after a given process has been performed. 
the removal of an additional $1.05 \%$ of the original amount of $C$ s present (99.92\% Cs removed overal1), yielding a CS DF of 1300 .

\subsubsection{Separation of Tc from Acidic Solution}

The results of tests on the solvent extraction of Tc (as pertechnetate ion) from acidic solution are summarized in Figure 3.4 and Table 3.7. The distribution coefficients for Tc obtained with TRUEX solvent and dilute $\mathrm{HNO}_{3}$ solutions are approximately three-fold higher than those reported by others, which were measured at a higher temperature of $40^{\circ} \mathrm{C}$ (Horwitz et al. 1985). The presence of $\mathrm{NaNO}_{3}$ had a large effect on the distribution of Tc in the TRUEX process. When the $0.5 \underline{\mathrm{M} \mathrm{HNO}} 3$ solution was increased to $5 \underline{\mathrm{M}}$ in $\mathrm{NaNO}_{3}$, the $D_{T c}$ decreased from 8.8 to 1.4 .

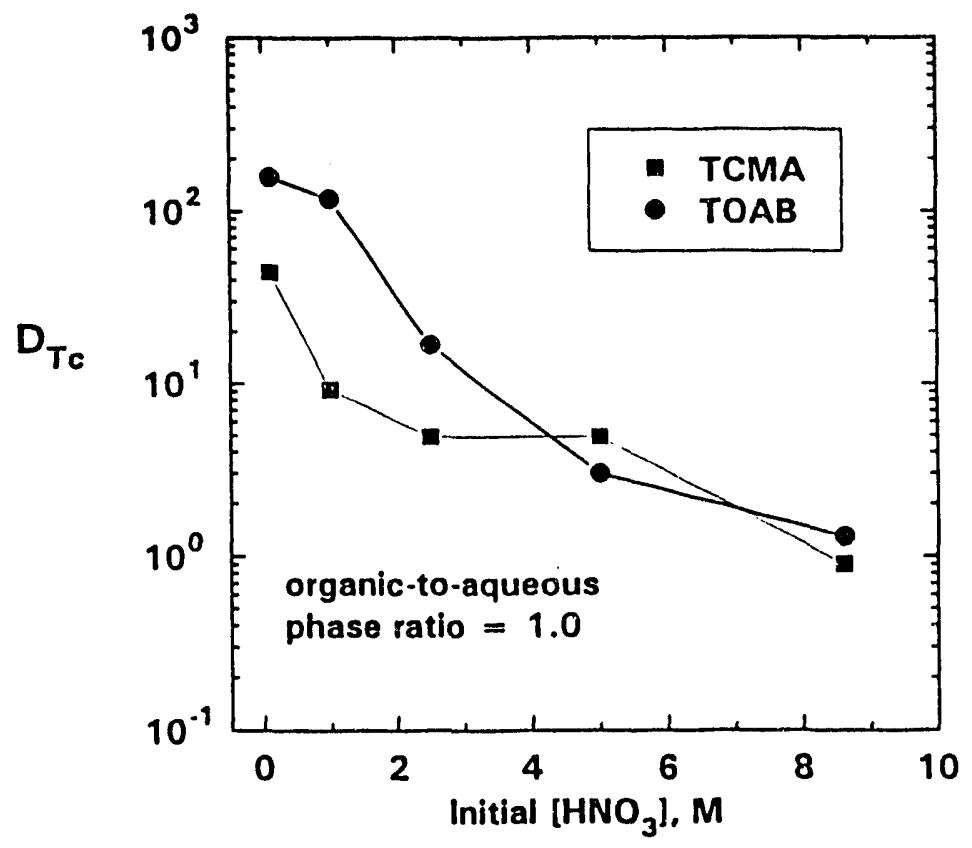

FIGURE 3.4. Extraction of Tc with 0.1 $\mathrm{M}$ TOAB in Cyclohexanone and 0.2 M TCMA in 1-Octanol as a Function of $\mathrm{HNO}_{3}$ Concentration 
TABLE 3.7. Extraction of TC from Acidic Solution

\begin{tabular}{|c|c|c|}
\hline Aqueous Phase & Organic Phase & $D_{\text {Tc }}$ \\
\hline $0.5 \mathrm{M} \mathrm{HNO}_{3}$ & TRUEX & 8.8 \\
\hline $0.5 \mathrm{M} \mathrm{HNO}_{3}$ & $0.1 \underline{M}$ TBAN in cyclohexanone & 126 \\
\hline $0.5 \mathrm{M} \mathrm{HNO}_{3}$ & $0.1 \mathrm{M}$ TOAB in cyclohexanone & 205 \\
\hline $0.5 \mathrm{M} \mathrm{HNO}{ }_{3}$ & $0.1 M$ TOAB in 1 -octanol & 12 \\
\hline $1.0 \mathrm{M} \mathrm{HNO}$ & TRUEX & 7.9 \\
\hline $1.0 \mathrm{M} \mathrm{HNO}$ & $0.1 \underline{M}$ TBAN in cyclohexanone & 62 \\
\hline $1.0 \mathrm{M} \mathrm{HNO}$ & $0.1 \mathrm{M}$ TOAB in cyclohexanone & 76 \\
\hline $1.0 \mathrm{M} \mathrm{HNO}$ & $0.1 \mathrm{M}$ TOAB in 1 -octanol & 7.9 \\
\hline $0.5 \mathrm{M} \mathrm{HNO}_{3}+5 \underline{\mathrm{M} \mathrm{NaNO}}{ }_{3}$ & TRUEX & 1.4 \\
\hline $0.5 \underline{\mathrm{M} \mathrm{HNO}}{ }_{3}+5 \underline{\mathrm{M} \mathrm{NaNO}} 3$ & $0.1 \mathrm{M}$ TBAN in cyclohexanone & 23 \\
\hline $0.5 \underline{\mathrm{M}} \mathrm{HNO}_{3}+5 \underline{\mathrm{M} \mathrm{NaNO}}{ }_{3}$ & $0.1 \underline{M}$ TOAB in cyclohexanone & 17 \\
\hline Simulated $\mathrm{CC}\left(0.5 \underline{\mathrm{M}} \mathrm{HNO}_{3}\right)$ & TRUEX & 2.2 \\
\hline Simulated $\mathrm{CC}\left(0.5 \underline{\mathrm{M}} \mathrm{HNO}_{3}\right)$ & $0.1 \underline{M}$ TBAN in cyclohexanone & 12 \\
\hline Simulated $\mathrm{CC}\left(0.5 \mathrm{M} \mathrm{HNO}_{3}\right)$ & $0.1 \mathrm{M}$ TOAB in cyclohexanone & 11 \\
\hline Simulated $\mathrm{CC}\left(0.5 \mathrm{M} \mathrm{HNO}_{3}\right)$ & $0.1 \underline{M}$ TOAB in 1 -octanol & 1.6 \\
\hline
\end{tabular}

Technetium was strongly extracted by solutions of tetraalkylammonium salts in cyclohexanone. The distribution coefficients for the extraction of Tc from $0.5 \mathrm{M} \mathrm{HNO}_{3}$ with $0.1 \mathrm{M}$ TBAN or $0.1 \mathrm{M}$ TOAB in cyclohexanone were 126 and 205 , respectively. The extraction of Tc by $0.1 \underline{M}$ TOAB in cyclohexanone as a function of $\mathrm{HNO}_{3}$ concentration is summarized in Figure 3.4. The distribution coefficient for Tc decreased with increasing $\left[\mathrm{HNO}_{3}\right]$ but very high $\mathrm{HNO}_{3}$ or $\mathrm{NaNO}_{3}$ concentrations would be needed to strip Tc from this solvent. A strip procedure involving the reduction of pertechnetate ion might prove more effective, however, such a method has not yet been developed (see Section 3.4.2).

As was observed with the TRUEX process solvent, the presence of $\mathrm{NaNO}_{3}$ suppressed the extraction of Tc with TOAB or TBAN in cyclohexanone. However, the distribution coefficients for Tc remained high enough for a workable process. Extraction of $T c$ from the acidified synthetic $C C$ waste $\left(0.5 \underline{M} \mathrm{H}^{+}\right)$with $0.1 \underline{M}$ TBAN or $0.1 \underline{M}$ TOAB in cyclohexanone yielded $D_{T c}$ of 12 and 11 , respectively. 
Because of its low flash point $\left(46^{\circ} \mathrm{C}\right)$, it is unlikely that cyclohexanone would be used in a large-scale process. Alternative diluents for the TOAB extractant were investigated in this study. TOAB was insoluble in NPH, but it did dissolve satisfactorily in 1-octanol. The distribution coefficients for the extraction of Tc by 0.1 M TOAB in 1-octanol were much lower than those obtained when cyclohexanone was the diluent. In the presence of high $\mathrm{NaNO}_{3}$ concentration, the suppression of the Tc extraction by TOAB was great enough that a viable process using l-octanol as the diluent is unlikely to be developed (at 0.i M TOAB).

The utility of using TCMA as an extractant for TC was investigated. This tetraalkylammonium chloride compound was insoluble in NPH, but soluble in 1-octanol. TCMA was converted to the nitrate salt because of the undesirability of the presence of chloride ion in nuclear waste processing. The extraction of Tc with 0.2 M TCMA as a function of $\mathrm{HNO}_{3}$ concentration is shown in Figure 3.4. The behavior of this extractant was similar to that of TOAB in cyclohexanone. The potential utility of TCMA in extracting Tc from acid solution is high, but a suitable method for stripping Tc will need to be developed.

\subsubsection{Separation of Sr from Acidic Solution}

One of the most effective methods of separating $\mathrm{Sr}$ from acidic solution is the SREX process currently under investigation at Argonne National Laboratory (ANL) (Horwitz et a1. 1991). This solvent extraction process uses a solvent consisting of $0.2 \mathrm{M}$ di-t-butylcyclohexano-18-crown-6 (DtBC18C6) in 1-octano1. An experiment was carried out to assess the suitability of this method for removal of ${ }^{90} \mathrm{Sr}$ from acidic CC waste solutions. A sample of acidified synthetic $C C$ waste $\left(\left[\mathrm{H}^{+}\right]=1.1 \mathrm{M}\right)$ spiked with ${ }^{85} \mathrm{Sr}$ was contacted successively with three portions of $0.2 \mathrm{M}$ DtBC $18 \mathrm{C} 6$ in 1 -octanol (organic-to-aqueous phase ratio of 0.33 for each contact). The distribution coefficients for $\mathrm{Sr}$ were $7.4,5.8$, and 6.4 for the three contacts, respectively. These values were slightly lower than the $\mathrm{D}_{\mathrm{Sr}}$ of $10\left(1.0 \mathrm{M} \mathrm{HNO}_{3}\right)$ reported by Horwitz et al. (1991), but this is not surprising considering variations observed with different lots of DtBC18C6 at ANL. Also, the values reported by ANL were 
recorded at $40^{\circ} \mathrm{C}$, while these reported here were measured at ambient temperature. The $\mathrm{Na}$ content of the feed solution used in the ANL study (0.15 M) was al so much less than that used here $(4.8 \mathrm{M})$.

The DF obtained using the SREX procedure was 40 , which is probably not sufficient to lower the ${ }^{90} \mathrm{Sr}$ levels in CC waste to below the Class A LLW criterion. Higher acid concentrations in the feed and an increased organic-toaqueous phase ratio (or more contact stages) would result in improved $\mathrm{Sr}$ removal. While a more carefui assessment is required to determine if SREX can adequately lower $\mathrm{Sr}$ levels to meet Class A LLW requirements, these initial results are considered promising.

\subsection{SEPARATIONS FROM ALKALINE SOLUTION}

Sorption and solvent extraction methods were evaluated for the removal of radionuclides from alkaline $C C$ waste supernate. The organic ion exchange resin BSC-187 and the inorganic sorbent TIE-96 showed promise for the separation of $\mathrm{Cs}$ and Pu. When treated with TCMA, TIE-96 also adsorbed TC. Tetraalkylammonium compounds showed promise for the extraction of Tc from alkaline CC waste supernate, but stripping of TC continues to be a problem. Efficient methods of extracting $\mathrm{Am}$ and $\mathrm{Sr}$ from alkaline $\mathrm{CC}$ waste supernate remain to be developed.

\subsubsection{Sorption Processes}

A series of solid sorbents was investigated for the removal of $\mathrm{Sr}$, Cs, $\mathrm{Am}, \mathrm{Pu}$, and Tc from alkaline solution. The affinity of each sorbent for the various elements of interest was determined using batch distribution measurements. For these measurements, the synthetic CC supernate was diluted with two volumes of water, spiked with an appropriate tracer $\left({ }^{85} \mathrm{Sr},{ }^{137} \mathrm{Cs},{ }^{241} \mathrm{Am}\right.$,

${ }^{239} \mathrm{Pu}$, or $\left.{ }^{99} \mathrm{Tc}\right)$, and contacted with the solid sorbent of interest. The results are summarized in Table 3.8.

The most promising sorbents investigated here were BSC-187 (resorcinolformaldehyde resin) (Bray et a1. 1990; Bibler et al. 1990) and TIE-96 (Bray and Hara 1991). Both of these materials displayed high affinity for Pu and 
TABLE 3.8. Batch Distribution Ratios for $\mathrm{Sr}, \mathrm{Cs}, \mathrm{Am}, \mathrm{Pu}$, and TC

\begin{tabular}{|c|c|c|c|c|c|}
\hline \multirow[b]{2}{*}{ Exchanger } & \multicolumn{5}{|c|}{ Batch Distribution Ratio, Rd } \\
\hline & $\mathrm{Sr}$ & $\mathrm{Cs}$ & $\mathrm{Am}$ & $\mathrm{Pu}$ & Tc \\
\hline BSC -187 & 0.3 & 826 & 42 & 1325 & 5 \\
\hline$C S-100$ & 0.8 & 58 & 38 & 189 & 10 \\
\hline ARC -359 & $<0.1$ & 25 & 47 & 931 & 11 \\
\hline IE -96 & $<0.1$ & 199 & 17 & 24 & 1.6 \\
\hline TIE-96(a) & 12 & 167 & 44 & 1327 & $<1$ \\
\hline$T I E-96 A^{(b)}$ & (c) & (c) & (c) & $(c)$ & 473 \\
\hline Charcoal & (c) & (c) & (c) & (c) & 70 \\
\hline
\end{tabular}
(a) IE-96 contained 5 wt\% $\mathrm{TiO}_{2}$.
(b) TIE-96 contained 9.8 wt\% TCMA.
(c) Not measured.

CS; BSC-187 had an exceptionally high affinity for CS (14 times that of (S-100). However, the affinities of these materials for the other of interest were generally low. When treated with TCMA, the affinity of TIE-96 for TC increased dramatically. Efficient sorbents for the separation of $\mathrm{Sr}$ and $\mathrm{Am}$ from alkaline CC waste have not been identified. BSC-187 and TIE-96 do have some affinity for Am, but whether or not adequate DFs for Am could be achieved with these materials is questionable. The addition of $\mathrm{Ti}$ to IE-96 (5 wt\% $\mathrm{TiO}_{2}$ $=$ TIE-96) resulted in a batch distribution ratio of 12 for $\mathrm{Sr}$. These promising results warrant further investigation in this area.(a)

\subsubsection{Solvent Extraction Methods}

Strontium-90. The extraction of $\mathrm{Sr}$ from alkaline solutions with dicyclohexano-18-crown-6 (DC18C6) plus a high molecular weight neocarboxylic acid (NCA) was performed by McDowell et al. (1986). The utility of this

(a) The sorption of $\mathrm{Sr}$ on sodium titanate was not investigated in this work because the literature suggested that the presence of organic complexants such as EDTA suppresses the sorption of $\mathrm{Sr}$ from highly alkaline media (Heinonen et al. 1981). 
method for the extraction of $\mathrm{Sr}$ from alkaline $\mathrm{CC}$ waste supernate was investigated in this study (Table 3.9). An extractant consisting of $0.05 \underline{M}$ $D C 18 C 6+0.1 M N C A$ in toluene, which had been preequilibrated with a sodium hydroxide $/ \mathrm{NaNO}_{3}$ solution, successfully extracted $\mathrm{Sr}$ from the alkal ine solution. However, the presence of complexants suppressed the extraction. For example, when a $0.45 \underline{\mathrm{M} \mathrm{Na}} \mathrm{CO}_{3}+0.45 \mathrm{M} \mathrm{NaOH}$ solution spiked with ${ }^{85} \mathrm{Sr}(-100 \mathrm{nC}$ ${ }^{85} \mathrm{Sr} / \mathrm{mL}$ ) was coniacted with $0.05 \mathrm{M} \mathrm{DC18C6}+0.1 \mathrm{M} N C A$ in toluene, the distribution coefficient for $\mathrm{Sr}$ was 149. $D_{S r}$ decreased to 0.12 when the aqueous phase also contained 0.009 M EDTA. Likewise, the $D_{S r}$ obtained in the extraction of $\mathrm{Sr}$ from synthetic CC waste supernate was 0.05 . Thus, this method showed little promise for the extraction of Sr from alkaline CC waste.

Technetium-99. The extraction of Tc from alkaline solution with cyclohexanone and tetraalkylammonium salts was investigated (Table 3.10). As had been previously reported, Tc is extracted from alkaline sclutions with cyclohexanone (Boyd and Larson 1960; Schulz 1980). The extraction by cyclohexanone is increased by adding tetraalkylammonium salts to the solvent. High eytraction of TC from the simulated CC waste supernate was achieved with $0.1 \mathrm{M}$ solutions of TBAN or TOAB in cyclohexanone $\left(D_{T C}=33\right.$ and 49 , respectively).

As mentioned in Section 3.3.2, the use of cyclohexanone on a large scale would be undesirable due to its low flasi vint. Thus, the use of 1-octanol as diluent was explored. Tc was well extracted from $1 \mathrm{M} \mathrm{Na}_{2} \mathrm{CO}_{3}$ by $0.1 \underline{M}$ TOAB in 1-octanol $\left(D_{T c}=110\right)$, but from more complicated matrices the distribution coefficient for Tc dropped dramatically $\left(D_{T c}=4.3\right.$ from the synthetic $C C$ waste supernate), probably due to competition between pertechnetate ion and nitrate ion. Thus, a suitable diluent remains to be identified.

TABLE 3.9. Extraction of Sr with $0.05 \underline{M} D C 18 C 6+0.1$ M NCA in Toluene

\begin{tabular}{lc}
\multicolumn{1}{c}{ Aqueous Phase (Spiked with ${ }^{35} \mathrm{Sr}$ ) } & $\frac{D_{S r}}{131}$ \\
\hline $0.5 \underline{\mathrm{M} \mathrm{Na}} \mathrm{CO}_{3}+0.5 \underline{\mathrm{M} \mathrm{NaH}}$ & 149 \\
$0.45 \underline{\mathrm{M} \mathrm{Na}} \mathrm{CO}_{3}+0.45 \underline{\mathrm{M} \mathrm{NaOH}}$ & 0.12 \\
$0.45 \underline{\mathrm{M} \mathrm{Na}} \mathrm{CO}_{3}+0.45 \underline{\mathrm{M} \mathrm{NaOH}}+0.009 \underline{\mathrm{M}}$ EDTA & 0.05 \\
synthetic CC supernate &
\end{tabular}


IABLE 3.10. Extraction of TC from Alkaline Solution

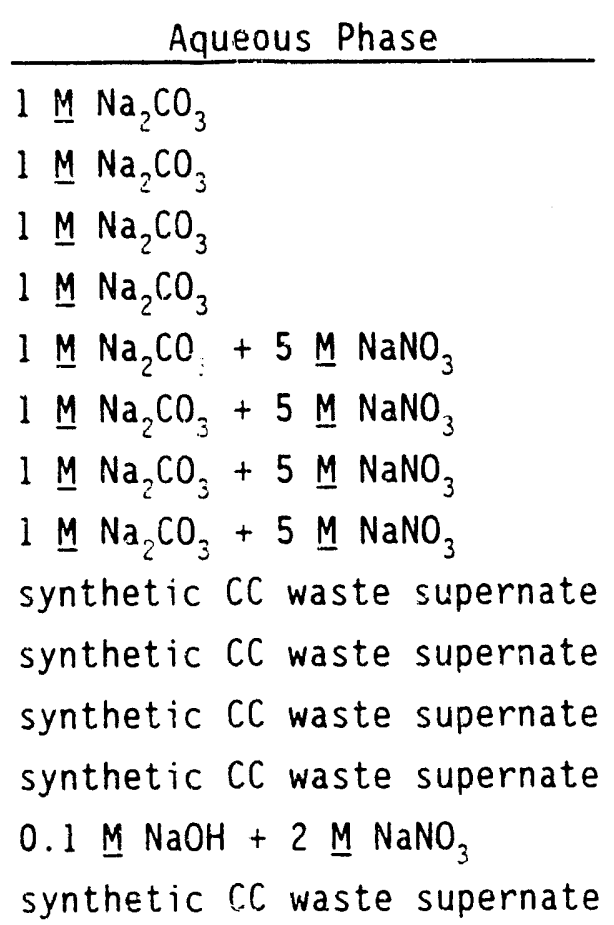

\begin{tabular}{lcc}
\multicolumn{1}{c}{ Organic Phase } & & $D_{\text {ic }}$ \\
\hline cyclohexanone & 10 \\
0.1 M TBAN in cyclohexanone & 78 \\
0.1 M TOAB in cyclohexanone & 285 \\
0.1 M TOAB in l-octanol & 110 \\
cyclohexanone & 4.7 \\
0.1 M TBAN in cyclohexanone & 102 \\
0.1 M TOAB in cyclohexanone & 49 \\
0.1 M TOAB in 1-octanol & 6.7 \\
cyclohexanone & 7.0 \\
0.1 M TBAi in cyclohexanone & 3.3 \\
0.1 M TOA in cyclohexanone & 49 \\
0.1 M TOAB in 1-octanol & 4.3 \\
0.2 M TCMA in 1-octanol & 5.2 \\
0.2 M TCMA in 1-octanol & 5.6
\end{tabular}

TCMA was observed to extract Tc from $=1$ laline solution. When a solution of 0.2 M TCMA in 1-octanol was used as extractant, the distribution coefficients for TC were 5.2 and 5.6 for extraction frum $0.1 \mathrm{M} \mathrm{NaOH}+2 \mathrm{NaNO}$ and the synthetic CC vaste supernate, respectively.

Attempts to strip Tc from cyclohexanone/tetraalkylammonium salt solutions under reductive conditions were unsuccessful. Several experiments were performed in which an organic phase containing Tc was contacted with a strip solution containing $\mathrm{Sn}^{2+}$ and EDTA (Table 3.11). It was expected that the $\mathrm{TCO}_{4}$ ion would be reduced by $\mathrm{Sn}^{2-}$, and the resulting Tc cation (oxidation state unknown) would be complexed by EDTA in the aqueous phase. The distribution coefficients for Tc decreased as $\left[\mathrm{Sn}^{2+}\right.$ ] increased, but they remained too high for efficient stripping even at $0.01 \mathrm{M} \mathrm{Sn}{ }^{i-}$. Thus, an effective method to strip Tc remains to be developed.

The effect of $\mathrm{pH}$ on the extraction of Tc with 0.1 M TOAB in l-octanol was explored (Table 3.12). The extraction of $T c$ is independent of $\mathrm{pH}$ in the range $\mathrm{pH} 1$ to 13 , suggesting that hydronium ion is not involved in the 
TABLE 3.11. Reductive Stripping of TC

\begin{tabular}{|c|c|c|c|}
\hline Extractant & Diluent & {$\left[\mathrm{Sn}^{2+}\right], \underline{M}$} & $D_{I_{c}}$ \\
\hline- & cyclohexanone & 0.01 & 34 \\
\hline TOAB & cyclohexanone & 0.001 & 77 \\
\hline TOAB & cyclohexanone & 0.01 & 34 \\
\hline TOAB & 1-octanol & 0.001 & 14 \\
\hline TOAB & 1-octanol & 0.01 & 1.5 \\
\hline
\end{tabular}

IABLE 3.12. Extraction of TC from $5 \mathrm{M} \mathrm{NaNO}_{3}$ Solution with 0.1 TOAB in 1-Octanol as a Function of $\mathrm{pH}$

\begin{tabular}{|c|c|}
\hline Initial $\mathrm{pH}$ & Equilibrium $\mathrm{pH}$ \\
\hline 0.65 & 0.73 \\
\hline 2.81 & 2.92 \\
\hline 7.18 & 5.41 \\
\hline 8.07 & 5.85 \\
\hline 8.12 & 5.72 \\
\hline 10.25 & 6.70 \\
\hline 12.70 & 12.79 \\
\hline
\end{tabular}

extraction mechanism. In most cases where the initial solution was alkaline, the $\mathrm{pH}$ dropped upon contact with $0.1 \mathrm{M}$ TOAB in 1-octanol. This was probably due to extraction of hydroxide ion by TOAB.

Americium. Research has been conducted by Myasoedov et al. (1980) and Karalova et al. (1984) on the extraction of Am from alkaline solution by alkylated catechol derivatives. Presumably, Am was present as one or more types of carbonate complexants in the aqueous phase. The possibility of applying this technique to the separation of Am from the alkaline CC waste supernate was investigated in this study. Three compounds were explored as possible extractants for Am: 4-t-butylcatechol (tBC), 3,5-di-t-butylcatechol (DtBC), and 4-(1-methyl-1-octylnonyl)catechol (MONC). (The compound MONC was used in the studies conducted in 1980 and 1984.) The results are summarized in Table 3.13. The alkylated catechols were found to extract Am from alkaline 
TABLE 3.13. Extraction of Am from Alkaline Solution with Alkylated Catechols

\begin{tabular}{|c|c|c|}
\hline Aqueous Phase & Organic Phase & $\mathrm{D}_{\mathrm{Am}}$ \\
\hline $0.5 \mathrm{M} \mathrm{Na}_{2} \mathrm{CO}_{3}+0.5 \mathrm{M} \mathrm{NaOH}$ & $0.2 \mathrm{M} \mathrm{DtBC}$ in 1 -octanol & 41 \\
\hline $0.5 \mathrm{M} \mathrm{Na}_{2} \mathrm{CO}_{3}+0.5 \mathrm{M} \mathrm{NaOH}$ & $0.2 \mathrm{M}$ DtBC in NPH & 420 \\
\hline $0.5 \mathrm{M} \mathrm{Na}_{2} \mathrm{CO}_{3}+0.5 \underline{\mathrm{M} \mathrm{NaOH}}$ & $0.2 \mathrm{M}$ tBC in 1 -octanol & 11 \\
\hline $0.45 \underline{\mathrm{M} \mathrm{Na}} \mathrm{CO}_{3}+0.45 \underline{\mathrm{M} \mathrm{NaOH}}$ & $0.2 \mathrm{M}$ tBC in 1 -octanol & 11 \\
\hline $\begin{array}{l}0.45 \mathrm{M} \mathrm{Na}^{2} \mathrm{CO}_{3}+0.45 \mathrm{M} \mathrm{NaOH} \\
+0.009 \underline{\mathrm{M}}^{2} \mathrm{EDTA}\end{array}$ & $0.2 \underline{\mathrm{M}} \mathrm{tBC}$ in 1 -octanol & 0.8 \\
\hline synthetic CC supernate & $0.2 \underline{M}$ DtBC in $N P H$ & 0.1 \\
\hline synthetic CC supernate & $0.2 \mathrm{M}$ DtBC in 1 -octanol & 0.01 \\
\hline $\begin{array}{l}0.5 \mathrm{M} \mathrm{Na} \mathrm{CO}_{3}+0.5 \mathrm{M} \mathrm{NaOH} \\
\text { synthetic } \mathrm{CC} \text { supernate }\end{array}$ & $\begin{array}{l}0.1 \text { M MONC in NPH } \\
0.1 \text { M MONC in NPH }\end{array}$ & $\begin{array}{l}>5000^{(a)} \\
0.01\end{array}$ \\
\hline
\end{tabular}

(a) Severe interfacial crud information.

solutions, but the presence of complexants suppressed the extraction. Thus, $D_{\text {Ain }}$ decreased from 11 for the extraction of Am from $0.45 \mathrm{M} \mathrm{Na}_{2} \mathrm{CO}_{3}+0.45 \mathrm{M} \mathrm{NaOH}$ with $0.2 \mathrm{M}$ tBC in 1 -octanol, to 0.8 for extraction from a similar aqueous phase that also contained $0.009 \mathrm{M}$ EDTA. Likewise, with $0.1 \mathrm{M}$ MONC in NPH, quantitative extraction of Am (organic-to-aqueous phase ratio $=1$ ) was obtained from a $0.5 \mathrm{M} \mathrm{Na}_{2} \mathrm{CO}_{3}+0.5 \mathrm{M} \mathrm{NaOH}$ solution; yet from the simulated $\mathrm{CC}$ supernate $D_{A m}$ was only 0.01 . Thus, this method is unsuitable for the removal of Am from alkaline CC waste supernate.

\subsection{TESTS WITH ACTUAL CC WASTE}

Several of the separation techniques described above were tested on actual CC waste. The results of these experiments are presented in this section. Experiments were performed using either diluted CC waste supernate or acidified CC waste supernate plus solids. The concentrations of the major components in the feed solutions used for these experiments are listed in Table 3.14. 
IABLE 3.14. Composition of Feed Solutions Used in Tests on Actual CC Waste

\begin{tabular}{|c|c|c|}
\hline Element & $\begin{array}{c}\text { Alkaline } \\
\text { Solution, } \underline{M} \\
\end{array}$ & $\begin{array}{c}\text { Acid } \\
\text { Solution, } \underline{M} \\
\end{array}$ \\
\hline$A 1$ & 0.0059 & 0.017 \\
\hline $\mathrm{Ca}$ & 0.0081 & not detected \\
\hline Cs & 0.000058 & 0.000043 \\
\hline $\mathrm{Fe}$ & 0.040 & 0.030 \\
\hline$k$ & 0.011 & 0.0063 \\
\hline$M n$ & 0.0088 & 0.0062 \\
\hline $\mathrm{Na}$ & 3.99 & 2.92 \\
\hline $\mathrm{Ni}$ & 0.0054 & 0.0037 \\
\hline$P$ & 0.0076 & 0.0060 \\
\hline$S r$ & 0.000031 & not detected \\
\hline${ }^{137} \mathrm{Cs}$ & $125 \mu \mathrm{Ci} / \mathrm{mL}$ & $84.4 \mu \mathrm{Ci} / \mathrm{mL}$ \\
\hline${ }^{96} \mathrm{Sr}$ & 110 & 89.0 \\
\hline${ }^{99} \mathrm{Tc}$. & 0.009 & 0.009 \\
\hline $239,{ }^{24 \theta} \mathrm{Pu}$ & 0.088 & 0.049 \\
\hline${ }^{238} \mathrm{Pu} /{ }^{241} \mathrm{Am}$ & 0.546 & 0.470 \\
\hline
\end{tabular}

\subsubsection{Precipitation of Cs with Sodium Phosphotungstate}

Experiments on the precipitation of CS from acidified synthetic CC waste suggested that high DFs for Cs can be achieved. Therefore, this method was evaluated on a sample of actual CC waste. A sample of the acidified real CC waste $\left(1.4 \mathrm{M} \mathrm{H}^{+}\right)$containing $3.4 \times 10^{-7}$ mole $C s$ was treated with two succes sive strikes of $\mathrm{Na}_{3} \mathrm{PW}_{12} \mathrm{O}_{40}\left(2.0 \times 10^{-6}\right.$ mole, then $\left.2.0 \times 10^{-5} \mathrm{~mole}\right)$. This treatment resulted in a decrease in the ${ }^{137} \mathrm{Cs}$ concentration from $84.4 \mu \mathrm{Ci} / \mathrm{mL}$ to $2.37 \mu \mathrm{Ci} / \mathrm{mL}$, giving a $\mathrm{DF}$ of 36 for Cs. Additional strikes with $\mathrm{Na}_{3} \mathrm{PW}_{12} \mathrm{O}_{40}$ would presumably lower the ${ }^{137} \mathrm{Cs}$ concentration to below the Class A LLW criterion (which is $1 \mathrm{Ci} / \mathrm{m}^{3}$ or $1 \mu \mathrm{Ci} / \mathrm{mL}$ ). Note that a large excess of $\mathrm{Na}_{3} \mathrm{PW}_{12} \mathrm{O}_{40}$ was required to precipitate the $\mathrm{Cs}$, in contrast to earlier studies and the results obtained with synthetic waste in this study (Section 3.3.1). 


\subsubsection{TRUEX: Behavior of TRUS and TC}

A portion of the acidified actual CC waste that had been treated with phosphotungstate was contacted three successive times with TRUEX solvent (organic-to-aqueous phase ratio $=0.33$ for all contacts, Table 3.15). Interfacial crud formed during each contact. Although, when a portion of the acidified CC waste that had not been treated with phosphotungstate was contacted with TRUEX solvent, no interfacial crud formed (contact 5). Therefore, if $C_{S}$ were to be removed by phosphotungstate precipitation, this process must be carried out after the TRUEX and SREX processes (see below), because interfacial crud forms when phosphotungstate is present.

TRUEX is a suitable process for the separation of TRUs from acidified CC waste solutions. The TRU content of the feed solution was $520 \mathrm{nCi} / \mathrm{mL}$, which decreased to $0.6 \mathrm{nCi} / \mathrm{mL}$ in the raffinate from contact 3 , giving a DF of 870 . The extraction behavior of the TRUs (and TC) in contact 5 was similar to that in contact 1 ; thus, even though interfacial crud formed in contacts 1 through 3 , the results obtained can be assumed to be similar to what would have been obtained if three successive contacts were performed with the feed not treated with phosphotungstate.

TABLE 3.15. TRUEX Experiment with Actual CC Waste(a)

\begin{tabular}{|c|c|c|}
\hline Contact & Aqueous Phase & Organic Phase \\
\hline $1^{\text {(b) }}$ & $\begin{array}{l}\text { Acidified CC waste } \\
\text { (after Cs ppt) }\end{array}$ & TRUEX \\
\hline $2^{(b)}$ & Aqueous from 1 & TRUEX \\
\hline $3^{(b)}$ & Aqueous from 2 & TRUEX \\
\hline 4 & $0.2 \mathrm{M} \mathrm{HEDPA}^{(\mathrm{c})}$ & Organic from 1 \\
\hline 5 & $\begin{array}{l}\text { Acidified } C C \text { waste } \\
\text { (before } C s \text { ppt) }\end{array}$ & TRUEX \\
\hline
\end{tabular}

\footnotetext{
(a) Organic-to-aqueous phase ratio $=0.33$ for al1 contacts.

(b) Interfacial crud formed during contact.

(c) 1-Hydroxyethane-1,1-diphosphonic acid.
} 
The TRUEX process was unsuitable for the extraction of Tc from acidified $\mathrm{CC}$ waste. The ${ }^{99} \mathrm{Tc}$ content was $8.8 \mathrm{nCi} / \mathrm{mL}$ in the feed solution, and $6.2 \mathrm{nCi} / \mathrm{mL}$ after contact 2. (a). The $D_{\text {TC }}$ for both contacts 1 and 2 was 0.6 . The lack of extraction of Tc by the TRUEX process was most likely due to the high nitrate concentration of the feed solution. (The effects of high $\mathrm{NaNO}_{3}$ concentration on the distribution of TC in TRUEX was discussed in Section 3.3.2.) However, another possibility is that the Tc was present in a reduced state and is complexed by the organics. Such a situation would greatly complicate Tc separation processes. This possibility cannot be dismissed at present.

The concentration of TC present in this sample of $C C$ supernate $(\approx 20 \mathrm{nCi} / \mathrm{mL})$ is already below the Class $A L L W$ criterion $\left(0.3 \mathrm{Ci} / \mathrm{m}^{3}\right.$ or $300 \mathrm{nCi} / \mathrm{mL})$. If this holds true for all CC wastes, then removal of TC will not be required.

\subsubsection{SREX: Behavior of Sr and TC}

A portion of the acidified actual CC waste that had been treated with phosphotungstate was contacted three successive times with SREX solvent (organic-to-aqueous phase ratio $=0.33$ for contacts 6 through 8 , Table 3.16 ). As was the case with TRUEX, interfacial crud formed in each contact. Strontium-90 was removed from the aqueous solution with a DF of $99(8.91 \times$ $10^{4} \mathrm{nCi}{ }^{90} \mathrm{Sr} / \mathrm{mL}$ in the feed; $8.96 \times 10^{2} \mathrm{nC} ;{ }^{90} \mathrm{Sr} / \mathrm{mL}$ in the raffinate from contact 8 ). In order to achieve a Class $A L L W$, the $D F$ for ${ }^{90} \mathrm{Sr}$ from this actual waste solution must be $2.2 \times 10^{3}$ (from an initial concentration of $8.9 \times 10^{4} \mathrm{nCi} / \mathrm{mL}$ to a final concentration below $40 \mathrm{nCi} / \mathrm{mL}$ ); an increased $\mathrm{DF}$ should easily be achievable by increasing the number of stages or the organicto-aqueous flow ratio.

As was observed with the TRUEX process, Tc was not extracted by the SREX process. The distribution coefficients for TC in contacts 6 and 7 were 0.5 . The possible reasons for the lack of Tc extraction are the same as those discussed above for the TRUEX process.

(a) The raffinate irom contact 3 was not analyzed for ${ }^{99} \mathrm{TC}$. 
TABLE 3.16. SREX Experiment with Actual CC Waste ${ }^{(a)}$

\begin{tabular}{|c|c|c|}
\hline Contact $\#$ & Aqueous Phase & Organic Phase \\
\hline $6^{(b)}$ & $\begin{array}{l}\text { Acidified CC waste } \\
\text { (after Cs ppt) }\end{array}$ & SREX \\
\hline $7^{(b)}$ & Aqueous from 6 & SREX \\
\hline $8^{(b)}$ & Aqueous from 7 & SREX \\
\hline 9 & $0.01 \mathrm{M} \mathrm{HNO}$ & Organic from 6 \\
\hline
\end{tabular}

(a) Organic-to-aqueous phase ratio $=0.33$ for a 11 contacts, except 9 where $0 / a=0.1$.

(b) Interfacial crud formed during contact.

\section{5 .4 Solid Sorbents}

The ability of various solid sorbents to remove ${ }^{90} \mathrm{Sr},{ }^{137} \mathrm{Cs},{ }^{241} \mathrm{Am},{ }^{239} \mathrm{Pu}$, and ${ }^{99}$ Tc from alkaline CC waste supernate was assessed by batch contact methods (Table 3.17). As expected from tracer experim. , the batch distribution measurements indicate that a workable Cs removal process could be developed (BSC-187, IE-96, TIE-96). On the other hand, the $R_{d} s$ for Pu were

TABLE 3.17. Batch Distribution Ratios for Sr, Cs, Am, $\mathrm{Pu}$, and TC, Obtained with Actual CC Waste

\begin{tabular}{|c|c|c|c|c|}
\hline \multirow[b]{2}{*}{ Exchanger } & \multicolumn{4}{|c|}{ Batch Distribution Ratio, $R_{d}$} \\
\hline & $\mathrm{Sr}$ & $\mathrm{Cs}$ & $\mathrm{Pu}$ & Tc \\
\hline $\mathrm{BSC}-187$ & 8.2 & 270 & 34.2 & 415 \\
\hline CS -100 & 7.4 & 29 & 25.4 & 175 \\
\hline ARC -359 & 4.9 & 11.4 & 19.2 & 239 \\
\hline IE-96 & 3.5 & 120 & 15.2 & 222 \\
\hline TIE $-96^{(a)}$ & 6.7 & 99.8 & 22.9 & 94.4 \\
\hline TIE-96A ${ }^{(b)}$ & 4.5 & 91.3 & 14.4 & 181 \\
\hline Charcoal & 8.2 & 4.1 & 14.8 & 256 \\
\hline
\end{tabular}

(a) IE-96 contained 5 wt\% Ti02.

(b) TIE-96 contained 9.8 wt\% TCMA. 
much lower than expected (based on results with synthetic waste, Table 3.8), and those for Tc were much higher than expected. The reasons for these results are unclear at present. Further work must be performed to confirm these unexpected results for actual CC waste. 


\subsection{CONCEPTUAL FLOWSHEETS}

A conceptual flowsheet based on the work performed in this study is shown in Figure 4.1. The first step on the flowsheet is separation of the solids and liquids. Then, the process splits: the processes on the left side of the flowsheet are performed on alkaline supernate; the processes on the right side, on acidified waste. There are two advantages in splitting these processes. First, direct acidification of the CC waste to dissolve the solids (option III, Figure 1.1) would greatly increase the volume of the LLW remaining after the separation of the radionuclides and reneutralization (for

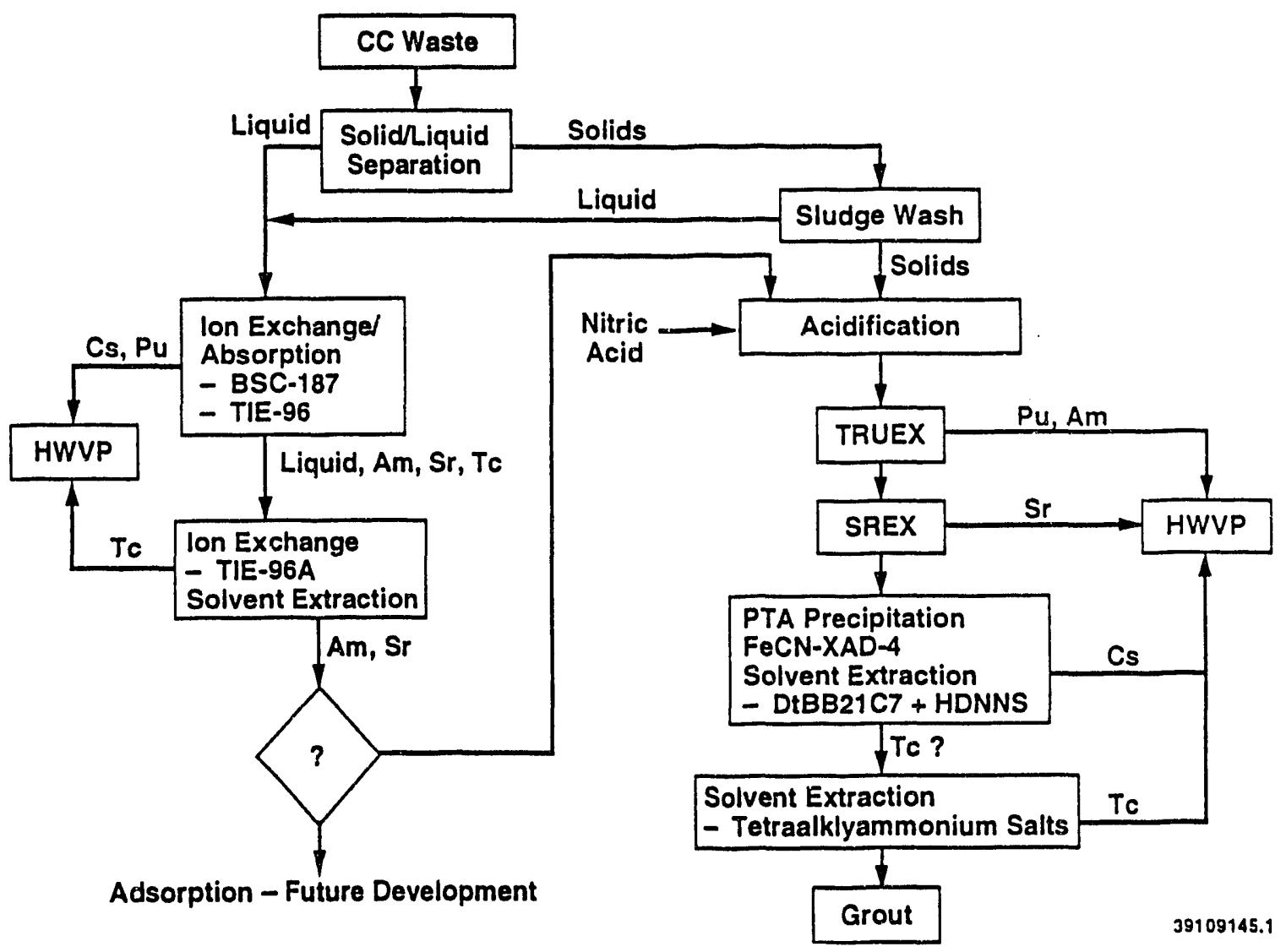

FIGURE 4.1. Conceptual Processing Flowsheet--CC Waste 
inter1.. urage in carbon steel tanks). (a) Second, the large quantities of $\mathrm{Na}$ present in the supernate interfere with the radionuclide removal efficiency of some of the acid-side separation processes.

As illustrated on the left side of the flowsheet, methods were identified for removing $\mathrm{Cs}, \mathrm{Pu}$, and $\mathrm{Tc}$ from the alkaline wastes. Two materials, one an organic (resorcinol-formaldehyde) resin (BSC-187) and the other a titaniumloaded zeolite (TIE-96), provide for removal of the Cs and Pu from the supernate. These materials could be vitrified directly. Essentially, the organic resins could be burned in the melter, although modifications to the construction and operation of the melter would be required. The loaded zeolite could more readily be vitrified with the existing design, but might result in a significant number of glass canisters being produced. Technetium could be removed from the alkaline liquid either with zeolite loaded with TCMA (TIE96A) or by solvent extraction methods. Technetium tends to volatilize during vitrification, but a recycle stream from the off gas back to the feed would allow the concentration of Tc to build up in the feed stream so that it can be satisfactorily loaded in the glass. Methods have not been identified to remove complexed Am or Sr from alkaline liquids.

An alternative processing sequence (Figure 4.2) for the ion exchange materials loaded during alkaline waste processing would involve elution of the $C s$ and possibly Pu from the BSC-187. Cesium is readily eluted from the BSC-187 using formic acid (Bibler et al. 1990), but the elution behavior of Pu is unknown. The TC and remaining Pu could be loaded on TIE-96A and vitrified.

Promising methods were identified for removing all of the radionuclides of interest from the acidic dissolved sludge solution (right side of Figure 4.1). The. TRUEX and the SREX solvent extraction processes are suitable for removing $\mathrm{Pu}, \mathrm{Am}$ (TRUEX), and Sr (SREX), al though SREX might not remove ${ }^{30} \mathrm{Sr}$ to a level acceptable for Class A LLW criteria. These processes have the potential to remove $T c$, but results obtained in this study with actual $C C$

(a) The effects of direct acidification upon the LLW volume could be minimized if an acid recovery step is included in the process. 


\section{Alternative Processing Sequence Alkaline CC Waste}

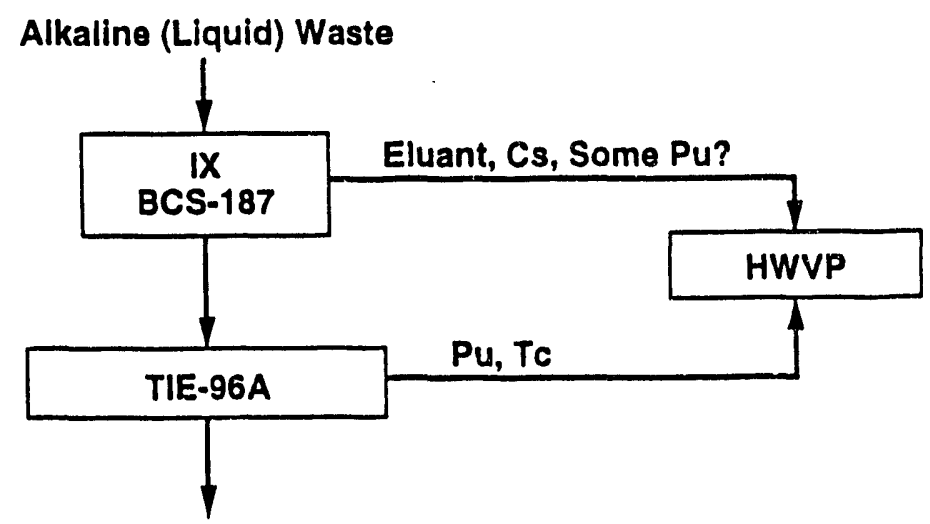

$\mathrm{Am}, \mathrm{Sr}$

391031452

FIGURE 4.2. Alternative Processing Sequence Alkal ine CC Waste

waste indicate that $T C$ is not extracted by TRUEX or SREX. Removal of TC, if necessary, could be achieved by solvent extraction using tetraalkylammonium salts or possibly tertiary amine extractants. Cesium can be removed by pre-

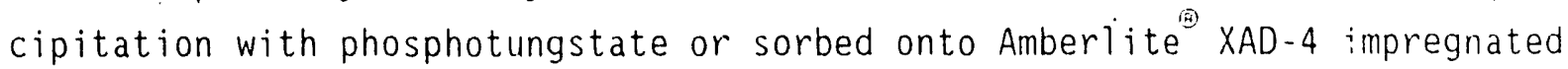
with FeCN-XAD-4 (providing adequate removal of $\mathrm{Na}$ by sludge washing has been achieved). It may also be possible to remove $C s$ by solvent extraction using DtBB21C7 and HDNNS in a suitable diluent.

Given the lack of suitable technologies for removal of complexed Am and Sr from alkaline solution, the best approach at present for removal of these radionuclides appears to be acidification of the entire CC waste followed by the use of the TRUEX and SREX processes. 


\subsection{DIRECTIONS FOR FUTURE RESEARCH}

A number of promising techniques for removing radionuclides from Hanford CC waste have been identified in this study. Each method should be further examined to fully assess its utility for treating CC waste. Other methods investigated in this study gave disappointing results, however, these results served to identify gaps in radionuclide separations technology. Recommendations for future research are made in this section.

\subsection{SOLIDS DISSOLUTION}

Acid dissolution of actual CC solids was investigated as part of this study (Section 3.2 ). The results suggested that $C C$ solids dissolve readily in $\mathrm{HNO}_{3}$. However, the solids in the actual CC waste sample used for this study might not be representative of the sludge that currently exists in Hanford tanks containing $C C$ waste. For this reason, it will be necessary to perform dissolution testing of $\mathrm{CC}$ solids actually removed from the tanks.

\subsection{SEPARATION OF CS FROM ACIDIC SOLUTION}

An efficient method of separating Cs from acidic ...lution has not been demonstrated. Three of the methods investigated in this study showed some promise for the removal of C.s from acidic media, but all three had serious shortcomings (Table 5.1). Another method, which was not investigated in this work, is the extraction of Cs with cobalt dicarbollide (Afonin et al. 1990). Although this method has been demonstrated to efficiently extract $\mathrm{Cs}$ from $\mathrm{HNO}_{3}$ solution, the ability to strip the $C_{S}$ from the solvent remains in question. Also, the method only works well when nitrobenzene is used as diluent. The use of such a highly toxic diluent in a large-scale operation is undesirable. Thus, much work remains to develop an acid-side process for Cs separation.

Research in the area of acid-side Cs separation should include efforts to: 1) search for suitable diluents for the DtBB21C7/HDNNS and the cobalt dicarbollide extraction methods, 2) develop methods of stripping Cs from the 
TABLE 5.1. Disadvantages of Acid-Side Cs Separations

Method

Extraction with

DiP? $21 C 7$ + HDNNS

Sorption on $\mathrm{FeCN}-\mathrm{XAD}-4$

Phosphotungstate Precipitation
Disadvantage

- Requires removal of $\mathrm{Na}$ by sludge washing

- Requires strong acid solution to strip CS

- Undesirable diluent (toluene)

- Requires removal of $\mathrm{Na}$ by sludge washing

- No method to elute Cs, requires disposal of Cs-loaded sorbent

- Affinity for Cs decreased upon storage

- Batch process

- Presence of PTA interferes with solvent extraction processes, method must follow TRUEX, SREX, etc.

DtBB21C7/HDNNS and the cobalt dicarbollide solvents, 3) develop new, more se1ective Cs extractants, and 4) investigate inorganic ion exchangers, especially ammonium molybdophosphate (Faubel and $A l i$ 1986). Testing of $S i-L$ with virgin material should also be performed.

\subsection{SEPARATION OF TC}

Extraction of TC from acidic or alkaline solution with tetraalkylammonium compounds shows great promise. The following areas of research are identified in order to develop a practical process:

- choice of extractant, e.g., TOAB or TCMA (availability, cost, and performance should be taken into account)

- effect of extractant concentration

- effect of diluent

- development of efficient method to strip TC.

The question as to whether removal of TC from DST wastes is necessary to meet Class A LLW criterion must also be addressed.

\subsection{SORPTION OF TRUS, Sr, CS, AND TC}

BSC-187 and TIE-96 show great promise for the removal of ${ }^{137} \mathrm{Cs}$ and $\mathrm{Pu}$ from alkaline $C C$ waste supernate. Issues that must be resolved to develop a practical process include: 
- use of real CC waste to confirm sorption processes for the various radionuclides on the solid sorbents

- capacity of the sorbents for the targeted radionuclides

- kinetics of adsorption

- elution of the targeted radionuclides from the sorbent.

- disposal of spent sorbent, e.g., vitrification or grouting

- modification of sorbent to remove other radionuclides, e.g., TIE-96A for TC

- assessment of whether adequate DFs for Am could also be attained using these sorbents.

\subsection{REMOVAL OF ${ }^{90} \mathrm{Sr}$ AND Am FROM ALKALINE CC WASTE SUPERNATE}

Efficient methods for removing ${ }^{98} \mathrm{Sr}$ and Am from alkaline $\mathrm{CC}$ waste supernate need to be developed. Technologies to achieve such separations do not appear to be near at hand. Fundamental understanding of the coordination chemistry of Sr(II) and Am(III) ions may be necessary for the development of suitable separation technologies. 


\subsection{REFERENCES}

Afonin, M. A., V. V. Korolev, V. N. Romanovskii, V. V. Romanovskii, and V. M. Sedov. 1990. "Improvements in Partitioning Process of Liquid Highly Radioactive Wastes by Using Cobalt Dicarbollyde Extraction." Presented at the International Topics Meeting, "Spectrum-90," Knoxville, Tennessee.

Bibler, J. P., R. M. Wallace, and L. A. Bray. 1990. "Testing A New CesiumSpecific Ion Exchange Resin for Decontamination of Alkaline-High Activity Waste." Presented at the 1990 Waste Management Meeting, Tucson, Arizona.

Boyd, G. E., and Q. V. Larson. 1960. "Solvent Extraction of Heptavalent Technetium." J. Phys. Chem. 64:988-996.

Bray, L. A., K. J. Carson, and R. J. Elovich. 1990. Cesium Recovery Using Savannah River Laboratory Resorcinol-Formaldehyde Ion Exchange Resin. PNL-7273, Pacific Northwest Laboratory, Richland, Washington.

Bray, L. A., and F. T. Hara. 1991. "Use of Titanium Treated Zeo? ite for Pu, Sr, and CS Removal from West Valley Alkal ine Wastes and Sludge Washes." Presented at the First Hanford Separation Science Workshop, Richland, Washington. PNL-SA-19697S, Pacific Northwest Laboratory, Richland, Washington.

Camaioni, D. M., N. G. Colton, and R. Bruening. 1991. Investigation of the Potential of Silica-Bonded Macrocyclic Ligands for Separation of Metal Ions From Nuclear Waste. PNL-7894, Pacific Northwest Laboratory, Richland, Washington.

Faubel, W., and S. A. Ali. 1986. "Separation of Cesium from Acid ILW-Purex Solutions by Sorption on Inorganic Ion Exchangers." Radiochim. Acta 40:49-56.

Heinonen, 0. J., J. Lehto, and J. K. Miettinen. 1981. "Sorption of Strontium(II) and Radio Strontium Ions on Sodium Titanate." Radiochim. Acta 28:93-96.

Hendrickson, W. F., and G. K. Riel. 1975. "Comparison of Ferrocyanides for Cesium Extraction." Health Physics 28:17-21.

Horwitz, E. P., D. G. Kalina, H. Diamond, G. F. Vandegrift, and W. W. Schulz. 1985. "The TRUEX Process - A Process for the Extraction of the Transuranic Elements from Nitric Acid Wastes Utilizing Modified PUREX Solvent." Solvent Extraction and Ion Exchange 3:75-109.

Horwitz, E. P., M. L. Dietz, and D. E. Fisher. 1991. "SREX: A New Process for the Extraction and Recovery of Strontium from Acidic Nuclear Waste Streams." Solvent Extraction and Ion Exchange 9:1-25.

Karalova, Z. K., L. M. Rodionova, and B. R. Myasoedov. 1984. "Americium Extraction from Alkaline Salt Solutions by Alkyl Pyrocatechol." Radiokhimiya 26:21-24. 
Lokken, R. 0., R. D. Scheele, D. M. Strachan, and A. P. Toste. 1991. Complex Concentrate Pretreatment: FY 1986 Progress Report. PNL-7687, Pacific Northwest Laboratory, Richland, Washington.

McDowel1, W. J., B. A. Moyer, G. N. Case, and F. I. Case. 1986. "Selectivity in Solvent Extraction of Metal Ions by Organic Cation Exchangers Synergized by Macrocycles: Factors Relating to Macrocycle Size and Structure." Solvent Extraction and Ion Exchange 4:217-236.

Myasoedov, B. F., Z. K. Karalova, V. S. Kuznetsova, and L. M. Rodionova. 1980. "Extraction of Americium and Europium from Alkaline Solutions by Alkylpyrocatecholates." Radiokhimiya 22:347-351.

Schulz, W. W. 1980. Removal of Radionuclides from Hanford Defense Waste Solutions. RHO-SA-51, Rockwell Hanford Operation, Richland, Washington. 


\section{DISTRIBUTION}

No. of

Copies

\section{OFFSITE}

12 DOE/Office of Scientific and Technical Iıformation

T. Fryberger

EM-542, Trevion II

U.S. Department of Energy

19901 Germantown Road

Germantown, MD 20874

J. C. Tseng

7A-075/FORS

U.S. Department of Energy 1000 Independence Avenue

Washington, DC 20585

S. M. Wolf

EM- 542

U.S. Department of Energy 12800 Middlebrook Road

Germantown, MD 20874

\section{ONSITE}

DOE Richland Field Office

J. M. Hennig, A5-21
No. of

Copies

6 Westinghouse Hanford Company

J. N. Appe1, R2-07

S. A. Barker, R2-07

W. B. Barton, L4-75

R. G. Cowan, L5-31

J. J. Holmes, L5-55

R. M. Orme, R2-07

34 Pacific Northwest Laboratory

L. Ba17ou, P7-18

L. A. Bray, P7-25

G. H. Bryan, P7-25

S. A. Bryan, P7-14

R. T. Hallen, K2-12

D. E. Kurath, P7-43

W. W. Laity, K2-15

M. A. Li lga, K2-12

G. J. Lumetta, P7-25 (15)

J. R. Morrey, P7-14

R. D. Scheele, P7-25

L. J. Sealock, K2-10

J. L. Swanson, P7-25

D. W. Wester, P7-25

Publishing Coordination

Technical Report Files (5) 

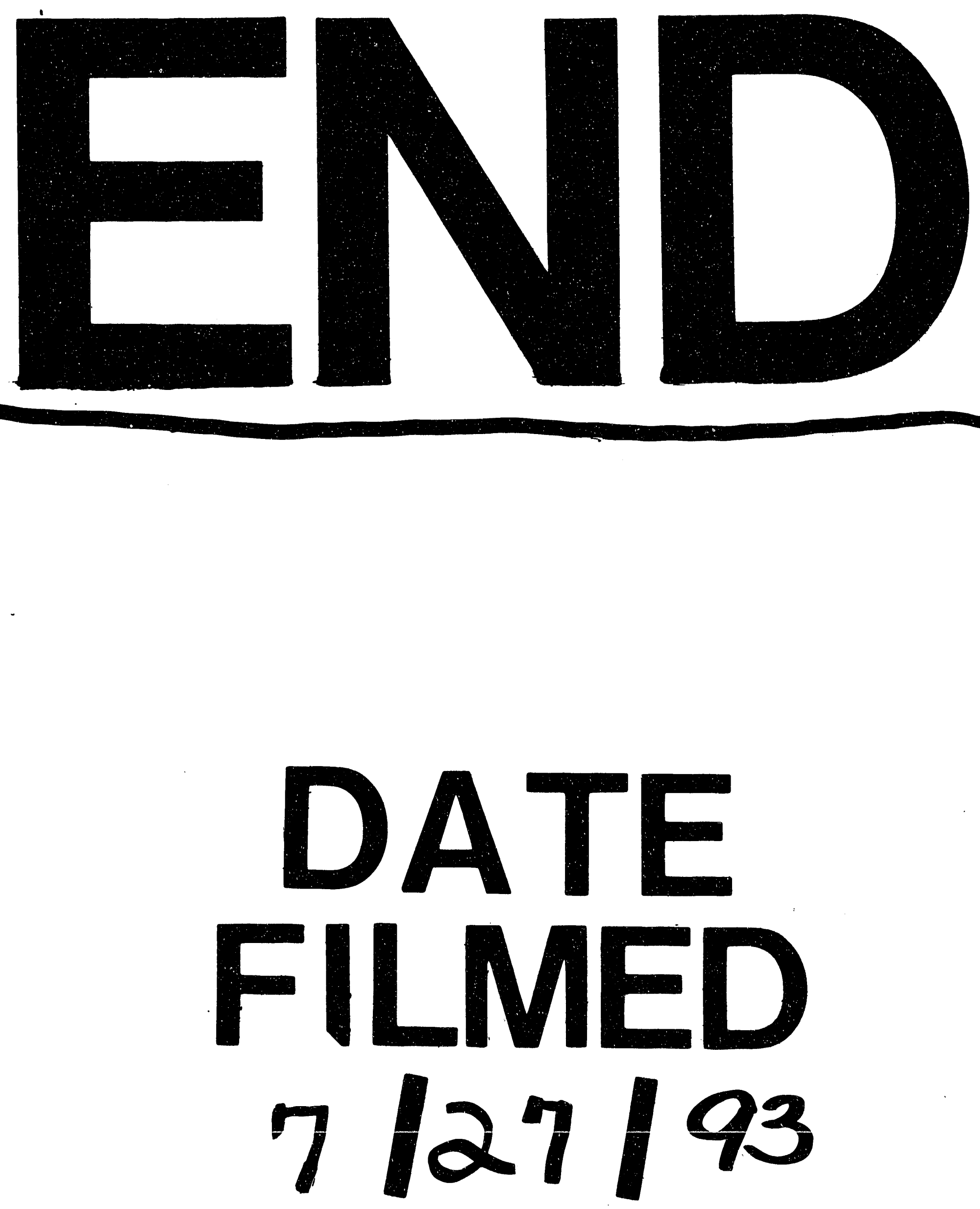
